\title{
MÚSICA Y LOCURA: DE LA CÍTARA DIVINA AL INDETERMINISMO
}

\author{
Daniel Martín Sáez \\ Universidad de La Rioja
}

\begin{abstract}
RESUMEN: La idea de inspiración musical, entendida como una especie de locura -divina y humana-, tiene una amplia tradición en Occidente, que arranca con los misterios griegos bajo la noción mitológica de entusiasmo, manía o furor divino (presente desde Homero hasta Platón), luego transformada en inspiratio durante la Antigüedad Tardía, la Edad Media y el Renacimiento, de significado religioso o teológico (como revelación o posesión demoníaca) pasando por las nociones de ingenio barroco en el siglo XVII, de genio natural-ilustrado y patológico-romántico en los siglos XVIII y XIX, hasta llegar a las vanguardias del siglo XX, donde se hace una idea cada vez más imprecisa y confusa. Intentamos comprender esta idea realizando su genealogía y analizando su desarrollo histórico.
\end{abstract}

Palabras clave: Manía, entusiasmo, inspiratio, afflatus, locura.

\section{MUSIC AND MADNESS: FROM DIVINE LYRE TO INDETERMINISM}

\begin{abstract}
The idea of musical inspiration, understood as a kind of madness -divine and human-, had a long tradition in the West, starting with the Greek mysteries under the mythological notion of enthusiasm, mania or divine furor (present from Homer to Plato), then transformed into inspiratio during Late Antiquity, the Middle Ages and the Renaissance, with religious or theological meaning (as revelation or demonic possession), through the baroque notion of ingenuity in the seventeenth century, the natural-illustrated and the pathologicromantic genius in the eighteenth and nineteenth centuries, up to the twentieth century avant-garde, where the idea of inspiration becomes increasingly blurred and confused. We try to understand this idea by mapping its genealogy and analyzing its historical development.
\end{abstract}

Keywords: Mania, enthusiasm, inspiratio, afflatus, madness. 


\section{Introducción}

Todavía hoy, cuando uno piensa en arte, y especialmente en música, no puede dejar de plantearse el problema de la inspiración: una idea quizá demasiado manoseada y equívoca, que atraviesa el núcleo de la mitología, la religión, el arte y la literatura, pero que también se encuentra presente en la historia de la creación científica, las hazañas guerreras o los discursos políticos. Los musicólogos no pueden hallar para ella un tratamiento satisfactorio, en la medida en que la música, entendida bajo la óptica de la disciplina, está muy alejada de cualquier idea que rebase el uso de conceptos técnicos: por la misma razón, la idea de inspiración desborda al resto de disciplinas, sin que pueda ser acogida siquiera por varias o incluso todas a la vez (como suelen pretender quienes piden, para cuestiones que escapan a una disciplina, un trabajo inter-disciplinar) ${ }^{1}$.

La pregunta por la inspiración musical, en este sentido, supone ya un revulsivo contra la musicología, contra su incapacidad para contestar a las preguntas centrales que subyacen al ámbito global de su disciplina. La propia cuestión "¿qué es la música?" se encuentra muy alejada de su campo de juego, pues no sólo implica en el camino a otras disciplinas que desconoce, y cuya involucración con el resto ni siquiera le interesa, sino que, en lo que resulta más esencial, exige un abordaje crítico de carácter filosófico capaz de atender, lejos de toda tendencia gremial o unívoca, al entramado de perspectivas simbólicas, técnicas, sociales, religiosas, políticas, ideológicas, etc., en el que esa idea surge y se desarrolla, calibrando sus implicaciones éticas, lógicas, estéticas, ontológicas, gnoseológicas.

Los musicólogos, qua talis, no saben nada sobre "música". Éste sería un buen comienzo, aunque suene provocativo, para comprender el problema de la inspiración. Parafraseando a Letamendi, también podríamos decir que quien sólo sabe música, ni música sabe o, para ser más drásticos, que los músicos -como los musicólogos- no piensan demasiado en la música (ni, por extensión, en las músicas): más bien se mueven en el plano de una de sus ideas, incluso aunque esa "una" sea, por ejemplo, la pluralidad de ideas que conforman la modalidad posmoderna de ver la música. Si el problema de la inspiración y la locura, o la simple idea de música, tienen algún interés para comprender el arte y la creación musical, eso ya debería servirnos para tomar una serie de precauciones.

Se podría mantener lo mismo sobre disciplinas mejor asentadas, como las matemáticas, la física o la química, pero nunca con tanta razón como cuando se habla del arte, de la música, de la inspiración o de la locura, cuatro nociones que

1. La razón es que no sólo habría que dilucidar qué disciplinas se reúnen y por qué, sino que el propio estudio exigiría un criterio y una metodología específicos, todo lo cual escapa al ámbito de trabajo de cada una de las disciplinas por separado e implica necesariamente una posición filosófica. 
siempre han sido ideas-límite, cercanas al mundo de lo irracional, lo diabólico, lo no-idéntico, lo religioso, y que parecen hablarnos más sobre lo que no-es que sobre aquello que es. Ya la propia palabra, "música", proveniente del término

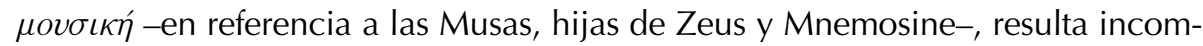
prensible sin la idea de inspiración, a su vez imbricada desde antiguo con la idea de locura, como vemos en el lón de Platón y, especialmente, en el Fedro.

Pero, ¿qué sabe el musicólogo de la locura o la inspiración? Lo mismo podría decirse del psicólogo (o del neurólogo), no sólo porque ya no utiliza la noción de locura, de la que nunca supo nada ${ }^{2}$, sino también porque nada sabe de música, cuando parece, como veremos, que la locura es inseparable de ella, junto a otras ideas que también escapan al dominio de cualquier disciplina positiva, tales como hombre, mundo, dios, amor, arte, religión, etc. Si atendemos al lugar que la locura ocupa desde Platón hasta la actualidad, a su importancia crucial en la historia de las ideas (no sólo de la historia escrita, sino también de la constatada en documentos judiciales, cárceles, hospitales, iglesias, templos, manicomios y otras instituciones), pronto nos daremos cuenta de hasta qué punto esta idea es incomprensible, y desde luego inútil para acometer una reflexión crítica, si no la abordamos filosóficamente.

\section{Algunas nociones básicas}

Lo primero que podemos afirmar sobre la inspiración es que no se refiere a una entidad u objeto determinado, sino al modo de aparición de entidades u objetos muy diversos. Quizá sea la idea más importante en nuestra manera de concebir el arte, al recoger el momento decisivo del acto creativo: la aparición del respirar, del afuera incontrolable que bulle dentro; lo que no es humano y, sin embargo, lo define, por ser su límite y sustento: el aire para los pulmones, el agua del arroyo, la madre y el padre, la infancia, los dioses, los animales. La locura sería el elemento donde la inspiración nace y se desenvuelve, el punto de contacto con el todo circundante, como el afuera que está dentro del adentro: no lo exterior interno, sino lo interior externo, el yo mismo sentido como dislocado que nos hace receptivos.

Aunque lo significativo no es tanto lo que tienen en común las ideas de inspiración históricamente existentes, sino cómo se articula esta idea a lo largo de recorridos históricos concretos -cada forma de concebir la inspiración llevará pareja una forma de comprender el arte-, resultará aclarador, de manera previa y orientativa, enumerar una serie de nociones básicas que se ligan a menudo a ella, sin perjuicio de que puedan cambiar o existan ya excepciones, para mos-

2. Esto puede afirmarse incluso desde coordenadas psicológicas, no sólo filosóficas: véase, e. g., Scull, Andrew, La locura: una breve introducción, trad. de E. Jáuregui. Alianza, Madrid, 2013, publicado en inglés en 2011. 
trar así su complejidad; pues no es que tengamos estas nociones básicas y, a partir de ahí, identifiquemos esta idea en cualquiera de sus contextos, sino que son éstos los que, en sus múltiples configuraciones, han ido dotando a la idea de inspiración de ciertos atributos. A pesar de la utilización masiva de esta idea (no hay prácticamente un libro de arte donde no aparezca el vocablo "inspiración"), apenas existe bibliografía que trate de abordarla críticamente. Por ello, nos contentamos aquí con mostrar su variedad, olvidada por musicólogos, periodistas, historiadores, críticos y teóricos.

Cualitativamente, la inspiración es extraordinaria, irracional y espontánea: nos muestra algo que no solemos ver, que nunca hemos visto o que debemos buscar, que no podemos explicar y que aparece ante nosotros sin nuestro claro consentimiento. Cuantitativamente, es intensísima: pensemos, e. g., en el éxtasis de Teresa de Ávila, en su poema "Vivo sin vivir en mí", o en la escultura dedicada a ella por Bernini, cuya analogía con el orgasmo podría ser bastante aclaradora (no por casualidad, la idea de sexualidad resulta históricamente inseparable de las ideas de locura e inspiración), aunque también podríamos pensar en el efecto de las drogas, cuya conexión con la idea de inspiración no es menor, como veremos. Temporalmente, aparece de repente y puede durar un instante, con independencia de lo mucho que revele o del impacto emocional que suponga su aparición (lo cual se explica por su intensidad). En relación al hombre, es externa: por eso se "inspira" y se entiende habitualmente como "posesión", al provenir de los dioses, la naturaleza, etc. Por último, su lugar de aparición es variable, pero tiene al hombre (entendido no sólo como individuo, sino también como colectividad, pueblo, etc.) como punto de encuentro, a quien suele revelar $y$, al mismo tiempo, enloquecer.

Es difícil encontrar excepciones a estas nociones, aunque a veces los conceptos den lugar a equívocos: es el caso, e. g., de la "exterioridad" de la inspiración, que en algunos románticos se supone interna al propio sujeto, o de la "psicología del arte" freudiana, en la que el inconsciente individual -el Ello, según la segunda tópica-, es la causa de la inspiración del artista. Pero, incluso en estos casos, la "interioridad" tiene mucho de exterioridad: e. g., la conciencia del Ego no puede comprehender lo inconsciente del Ello, que siente como extraño, y lo mismo ocurre con otros contra-ejemplos, donde la herencia recibida es más fuerte de lo que podría parecer.

En cuanto al qué de lo inspirado, puede expresarse en los términos de su fuente, no necesariamente inequívocos (pensemos en los mensajes ambiguos del Oráculo de Delfos o de las brujas del Macbeth de Shakespeare), en términos humanos fácilmente comprensibles (como cuando Dios aparece ante Abraham para pedirle que mate a su hijo Isaac en Gn 22, 1-19), o no buscar ningún tipo de mensaje, sino más bien provocar un estado "espiritual" (como ocurriría en ciertos rituales de purificación), o un conjunto de acciones políticas guiadas (como la conquista del Nuevo Mundo: según algunos, inspirada por Dios, en la línea del derecho divino de los reyes) o una experiencia intuitivo-contemplati- 
va intraducible (donde se incluiría desde algo tan abstracto como la intuición intelectual del Uno en la doctrina de Plotino hasta algo tan concreto como la audición completa de obras todavía no escritas en la mente del compositor, según el famoso mito sobre Mozart).

Además, la inspiración puede ser directa o indirecta. Si la inspiración se da a través de un cauce determinado, pero la entidad reveladora es distinta de éste, de manera que ha tomado ese cauce como podría haber tomado cualquier otro, entonces hablaríamos de una inspiración indirecta: e. g., en la tradición judeocristiana, es común que la divinidad se revele a través de profetas, apóstoles o sueños, aunque también podríamos acudir a ciertos "descubrimientos" de tipo científico o filosófico como el famoso "Eureka" de Arquímedes (inspirado por su inmersión en la bañera), o los sueños del cogito de Descartes y de la tabla periódica de Mendeleiev (aunque estos casos formen parte de una noción menos fuerte de inspiración, como el fenómeno del serendipity). Si, por el contrario, es el propio "cauce" el que parece revelarnos algo, en su particular lenguaje y con independencia de cualquier otra entidad externa, entonces hablaríamos de una revelación directa, como cuando Schopenhauer hace de la música la expresión de la voluntad cósmica.

Los límites entre revelación directa e indirecta son a menudo difusos, como cuando Dios se dirige a Moisés en forma de zarza ardiente (Ex 3), pero en otros casos es esencial: en la Antigua Grecia, por ejemplo, la historia de las hazañas de los antiguos héroes inspiraba a los guerreros, no por sí misma, sino por la forma en que era relatada y por el valor que mostraban sus protagonistas. De una manera muy distinta, incluso opuesta, ocurre en la especulación hegeliana, donde la propia historia es una inspiración directa, anónima e inconsciente, que ni siquiera necesita ser conocida por sus actores, hasta el punto de ser ella la que, enloqueciendo a los hombres -que formarían parte de una locura superior (al menos mientras llega la filosofía absoluta para comprenderla)- los maneja a su antojo. Esto tiene consecuencias esenciales. En Hegel, todos inspiraríamos en la historia nuestros actos, aparentemente libres, para llegar un día a una libertad superior; en los griegos, nuestra libertad para seguir a los héroes sería la clave de nuestra inspiración, y toda libertad no alcanzada en la lucha no serviría de nada.

Otro caso evidente lo encontramos en el efecto de las drogas, tradicionalmente entendidas en clave mágico-religiosa, como un preparativo para comunicarse con la divinidad (e. g., en los misterios eleusinos). En la historia reciente, sin embargo, se ha llegado a entender como una forma directa de alterar nuestro estado de ánimo o nuestra manera convencional de ver la realidad (e. g., en la poesía de Baudelaire o en la música psicodélica), sin perjuicio de que siga funcionando aquí algún componente mágico, al suponerse que la droga es capaz de inspirar por sí misma.

La entidad "inspirada" no es menos plural: la inspiración puede encontrarse en el universo, la naturaleza, la mitología, la religión, las matemáticas, la historia, 
la tradición, los rituales, la nación, el pueblo, el inconsciente, las patologías, los sueños, el arte, el amor, el alcohol, las drogas, el sexo, la música. Hay casi tantas formas de comprender la inspiración como civilizaciones, épocas históricas, naciones, pueblos, incluso comunidades, grupos sociales o individuos, y a veces están tan ligadas entre sí que resulta imposible entenderlas por separado. Además, podrían realizarse tantas clasificaciones dentro de cada uno de estos tipos, cuya conexión con el resto resultaría inevitable, que al final carece de sentido tomarlas como si tuviesen una lógica independiente: parece mucho más adecuado seguir su desarrollo histórico en algún punto concreto, mostrando su complejidad, para ver si esta idea tiene hoy alguna relevancia. La dificultad forma parte de la propia idea de inspiración, que favorece esta pluralidad de lecturas.

Para complicar todavía más las cosas, sobre todo en lo que se refiere al arte, habría que tener en cuenta dos líneas de pensamiento que, en principio, estarían en discordia con la idea de inspiración, pero que no han dejado de formar parte de nuestra tradición y mezclarse con ella: por una parte, la concepción inaugurada por Aristóteles que hace de la inspiración una especial disposición del ánimo, denominada melancolía ( $\mu \in \lambda a \gamma \times 0 \lambda \iota a$, la "bilis negra" de la medicina hipocrática), y que, por tanto, explica la creación artística a partir de elementos patológicos o médicos ${ }^{3}$; por otra, la que hace de la inspiración una simple metáfora para hablar de "influencia", que sería una noción mucho más adecuada y menos ambigua, al no ocultar el momento fundamental del aprendizaje, el apoyo institucional y el trabajo consciente. A esto parecía referirse Picasso cuando sostuvo irónicamente que la inspiración existe, pero que debe encontrarte trabajando, o Pablo de Sarasate, cuando afirmó: “¡Un genio! ¡He practicado catorce horas diarias durante treinta y siete años, y ahora me llaman genio!", o Cole Porter, cuando contestó a un periodista: "toda la inspiración que necesito es la llamada de un productor" ${ }^{\prime 4}$, y lo demostrarían innúmeros casos, como la descripción de Poe sobre la meditada composición de su célebre poema, El Cuervo ${ }^{5}$.

Ambas concepciones se opondrían, respectivamente, a la forma de concebir el arte como locura divina y revelación, creando una tensión irresoluble entre una manera "racional" de concebir el arte (como melancolía e influencia) y otra "irracional" (como locura y revelación), que formarían los extremos ideales de un espectro con diversos puntos intermedios. Quizá ambas juntas, no por separado, podrían darnos la clave para comprender la idea de arte en nuestra tradición.

3. Aristóteles, El hombre de genio y la melancolía (problema XXX), trad. de C. Serna. Acantilado, Barcelona, 2007.

4. Crofton, Ian y Fraser, Donald, La música en citas. Robinbook, Barcelona, 2001, p. 151.

5. Allan Poe, Edgar, "Filosofía de la composición", en Obras completas, trad. de Julio Cortázar, Tomo II. Aguilar, Madrid, 2004. 


\section{Genealogía de la locura e inspiración divina}

La historia de la locura y la inspiración es inseparable de la historia humana. La necesidad biológica de acometer acciones irracionales hace de la locura mucho más que una mera anormalidad, siendo más bien una idea inseparable de la especie. De nuestra "racionalidad" (tradicionalmente entendida) y de lo que parece incompatible con ella -empezando por la propia heterogeneidad del yo- surge nuestra idea de locura: quizá la más importante (más incluso que la idea de razón, a la que incluiría) para acometer nuestra antropología.

Aunque bastaría con comparar a dos individuos de la misma especie, la convivencia entre el Homo sapiens y el Neandertal podría ser más ilustrativa: el primero participaba de una especial locura (según la etimología, otra forma de Ilamar a la estupidez) ausente en el segundo; por ejemplo, sólo el Homo sapiens sería capaz de lanzarse al océano sin que hubiese un horizonte visible y habitable al otro lado. Un Neandertal, según el biólogo especialista en genética evolutiva Svante Pääbo, jamás realizaría tal locura (aunque, por descontado, realizaría otras $)^{6}$. Al margen de la veracidad de la anécdota, es innegable que todas las especies participan de su especial locura, de sus impulsos absurdos y arbitrarios, no-racionales, no calculados, extraños al resto de especies. Pero con más motivo lo diríamos del hombre, por su capacidad para hacerse cargo de su no-racionalidad, de sentirla como algo que le condiciona y que, sin embargo, no puede controlar. Este hecho podría ilustrar por qué, desde la prehistoria, la locura ha sido mucho más que un fenómeno marginal de la vida o una simple a-normalidad (como ocurrirá en parte a partir del siglo XVII en Europa, si creemos a Foucault): un elemento fundamental e irrenunciable de la comunidad donde la distinción entre lo religioso y lo profano, entre lo humano y lo divino, es apenas distinguible, como entre lo racional y lo irracional.

Lo mismo podría afirmarse sobre el momento prehistórico de la música, esencial para comprender los rituales religiosos y la organización de la vida comunitaria. La relación entre la música y el amor (o el sexo), ha sido destacada una y otra $v^{7} z^{7}$, pero, ¿por qué no hablar, más generalmente, de su relación con la locura? El sentido del oído encaja a su manera con la idea de "inspiración": algo que viene de fuera y entra en nosotros hasta poseernos, haciéndonos perder el control de nuestros actos. La relación del ritmo con el cerebelo -situado en la parte más antigua del cerebro y la más alejada de toda racionalidad "humana" (filogenéticamente hablando)-, o su influencia sobre el sistema respiratorio y la circulación, tan explotada en la danza, facilita esta idea de

6. Gitschier, J. (2008), "Imagine: An Interview with Svante Pääbo". PLoS Genet 4 (3): e1000035. doi:10.1371/journal.pgen.1000035.

7. Véase Valls, Manuel, La música en el abrazo de Eros. Aproximación al estudio de la relación entre música y erotismo. Tusquets, Barcelona, 2002. 
posesión, de locura, de irracionalidad, tan esencial en la música, que parece obligarnos a movernos, a bailar, a respirar, sin que podamos resistirnos (recordemos que la distinción entre música y danza es históricamente reciente).

La idea del amor, por su parte, se asienta desde diversas perspectivas que también han ido saliendo a la luz a lo largo de la historia, desde las cuatro formas de locura de Platón, donde música y amor conformarían dos de ellas, pasando por la teoría de los afectos del siglo XVII, hasta la teoría del lenguaje musical de Rousseau ${ }^{8}$ y la tesis biológico-funcionalista de Darwin (pensemos en los bailes zoomórficos y los cantos de cortejo) ${ }^{9}$ que llegan hasta la estética romántica del sentimiento y sacan a relucir la conexión de la música con el carácter emocional, también irracional, de nuestros deseos y pasiones: un caso reciente y significativo es Music and Sentiment (2010) de Charles Rosen ${ }^{10}$, que demuestra cómo esta línea no tiene por qué derivar en una idea parcial de la música, como es común en nuestra tradición, donde su conexión con la "racionalidad", las matemáticas, el lenguaje, la memoria o la cognición en general convive con lo anterior. Como ha puesto de relieve el neurólogo Gottfried Schlaug, la música exige una entrega total, siendo difícil encontrar una parte del cerebro que no sea activada por ella"

Lo que no se ve ni puede verbalizarse -los dioses, el amor, la frontera en el horizonte del océano- es acogido por la música: su temporalidad, frente al espacio visible, permite la llegada de acontecimientos imprevistos. Lanzarse al mar y encontrar algo -aunque sea la muerte- es cuestión de tiempo: ¿por qué ceñirse al mundo espacial de la visión? La música juega con el elemento del cambio y la sorpresa. Es una pena que tengamos que esperar a Homero y, sobre todo, a Platón, para encontrar las primeras huellas escritas de esta relación originaria, más allá de la arqueología. También sería interesante escudriñar algunas ideas orientales: el Nirvana, por ejemplo, que elimina la conciencia, o ciertas divini-

8. Para un compendio de las ideas de J.-J. Rousseau sobre música, véase Ferrer Mas, Anacleto (ed.), Rousseau: Música y Lenguaje. PUV, Valencia, 2010.

9. Darwin, Charles, El origen del hombre, trad. de Julián Aguirre. Edaf, Madrid, 2004. En su Tercera Parte, Capítulo XIX, se afirma que "Ios tonos musicales y el ritmo fueron empleados por nuestros antecesores semihumanos en el periodo de la seducción", sospechándose además que "Ios sonidos musicales fueron una de las bases del desarrollo del lenguaje" (p. 480).

10. Rosen, Charles, Música y Sentimiento, trad. de Luis Gago. Alianza, Madrid, 2012.

11. Véase, por ejemplo, Schlaug, Gottfried, "Listening to and Making Music Facilitates Brain Recovery Processes". Ann NY Acad Sci 2009, 1169: 372-373, en cuyo primer párrafo se afirma lo siguiente: "Emerging research over the last decade has shown that long-term music training and skill learning can be a strong stimulator for neuroplastic changes in the developing as well as adult brain. Making music places unique demands on the nervous system, leading to strong coupling of perception and action mediated by sensory, motor, and multimodal integrative regions distributed throughout the brain. Furthermore, listening to music and making music ("musicking") provokes motion, improves and increases between-subject communication and interaction, and is considered to be and experienced as a joyous and rewarding activity". 
dades del hinduismo, como los gandharvas, excelentes músicos que comunican a los hombres con los dioses y la naturaleza y que, como en Grecia, dan lugar a una música con poderes medicinales. Esto nos demostraría la gran ligazón que existe entre la música, la religión y la locura. Todas ellas querrían situarnos ante lo "absolutamente otro", aquello que no podemos apresar con conceptos ni asimilar con la conciencia, pero que se nos aparecería como (lo) esencial, aunque también como lo más caótico.

En Sacred Sound: experiencing Music in World Religions (2006), Guy L. Beck nos recuerda que no se conoce ninguna religión en la que la música no juegue un papel central, y no como algo accesorio, sino indisolublemente ligado a ella. Se demuestra el desconocimiento de base de las disciplinas que se encargan todavía hoy de estudiar la música y la religión como si fuesen realidades separadas, reduciendo la religión a una lista muerta de creencias más o menos fantasiosas y olvidando así sus diversas funciones sociales, psicológicas o cognoscitivas, inseparables de una praxis vital concreta ${ }^{12}$. Esta idea es esencial para nuestro propósito -y lo será cuando hablemos de John Cage, la música espectral o el minimalismo-, en la medida en que, en todas las religiones, está implicada una idea de inspiratio a través de una música que no se refiere a los creadores, sino que se aplica a los miembros de la comunidad. Los salmos judíos, como el Corán, los Vedas o los sutras del budismo, hay que "inspirarlos" a través de su interpretación musical: no basta con leerlos, pues la religión -según su propia lógica- es incomprensible sin escuchar. La unión entre música, inspiración, religión, amor, sexo, locura, parece más que una simple ocurrencia. Por razones de espacio, pero también porque la idea de música es típicamente griega y sólo se discute de manera rigurosa a partir de Pitágoras y Platón, nos centraremos en algunos casos de nuestra tradición.

\section{Entre los rituales mistéricos y Platón}

En general, las fuentes antiguas consideran a Orfeo anterior a Homero, aunque ni éste ni Hesíodo lo citan nunca, lo que en parte supone (como en el caso de Dionisos) un intento de asegurar la prioridad de la música sobre la poesía. Su padre podría ser Apolo y, con seguridad, su madre es Calíope. Con su música, Orfeo era capaz de conmover a peces, aves, fieras, árboles, e incluso a rocas, sirenas y dioses infernales. Poeta, mago, filósofo, chamán, figura legendaria, posible inventor del alfabeto, este dios del canto y la lira parece un espejo del arte musical: siempre en el límite, entre los vivos y los muertos, entre lo comprensible y lo inefable, como la sombra de Eurídice que, según Platón, se le mostró en el Hades, a cuyo dios también conmovió (Banquete 179d). Bajo su

12. Véase Beck, Guy L. (ed.), Sacred Sound: experiencing Music in World Religions. Wilfrid Laurier University Press, Waterloo, CA, 2006. 
leyenda, la frontera entre la realidad y el mito se difumina: se dice que su cabeza siguió cantando, una vez separada de su cuerpo por las furiosas ménades, mientras viajaba sobre su lira a la isla de Lesbos (allí habría permanecido, según algunas fuentes, para disfrute de los visitantes) ${ }^{13}$.

Aunque naturaleza y mito tampoco estén separados en Homero y Hesíodo, encaja mejor con Orfeo este ir y venir entre lo racional y lo irracional, al situarse en un punto intermedio entre lo propio de Grecia y lo que Grecia consideraba impropio. Orfeo no es un personaje griego, sino más bien un bárbaro, esto es, alguien a quien no se entiende cuando habla, como la música cuando es abandonada por la palabra. Sin embargo, los griegos lo han adoptado como alguien al que le está permitido habitar la frontera, al mismo tiempo dentro y fuera del logos, modificando la religión y la filosofía intramuros. El momento de la transgresión de Orfeo es muy significativo, tanto como la cólera de Aquiles en la llíada o los relatos de Sherezade en Las mil y una noches. Pero el orden impuesto por Agamenón o el rey Shahriar parece un juego respecto a la transgresión del dios de la música: su entrada en el Inframundo y su promesa de una vida futura elimina las barreras del orden establecido entre lo humano y lo divino.

Los rituales órficos (no siempre distinguibles de los dionisíacos, los pitagóricos o los eleusinos) implican un proceso de purificación y contacto con los dioses en el que, sin lugar a dudas, la música jugaba un papel insustituible. Se soportan bajo una concepción cíclica del tiempo, por analogía con la circularidad de las estaciones, las cosechas y la propia vida, en la que buscan influir. Lo importante, y por eso sería tan errado reducir el orfismo a sus textos, es el estado anímico que se persigue: una anticipación de la muerte corporal, una muerte en vida (recordemos de nuevo a Teresa de Ávila y su "muero porque no muero") que debía provocar un momento de éxtasis o entusiasmo (etimológicamente, "endiosamiento" o "posesión divina", que es la palabra que luego derivaría en inspiratio), acompañado o seguido de una purificación. La abstinencia sexual de Orfeo y su vegetarianismo podrían ligarse a toda una serie de prácticas, muy comunes en otras religiones y que tampoco están explicadas con detalle en los textos: el travestismo, la pederastia, el ayuno, la homosexualidad ritual, tanto como la virginidad, la castidad, la castración o la abstinencia, son solamente algunas de las maneras en que el hombre ha buscado situarse en el límite, entre el ser y el no ser, entre la vida y la muerte, entre la razón y la locura, entre el sueño y la vigilia, entre el pasado y el futuro, desdibujando los límites sociales y biológicos: lo griego y lo bárbaro, el ciudadano libre y el esclavo, el hombre y la mujer, los dioses y los animales. La milenaria petición filosófica de ascetismo e imperturbabilidad podría comprenderse como una secularización de esta idea religiosa.

13. Bernabé, Alberto y Casadesús, Francesc (coords.), Orfeo y la tradición órfica. Akal, Madrid, 2008. 
Sabemos poco del papel concreto de las drogas, el sexo y la música en este proceso, pero su presencia es innegable, junto a banquetes, sacrificios y libaciones. Así ocurre en los rituales iniciáticos de los misterios de Eleusis, celebrados en honor a Deméter y Perséfone durante casi dos milenios. Por desgracia, y debido en parte a su secretismo, desconocemos los detalles de sus orígenes, el papel de los disfraces, las drogas, las fiestas nocturnas, las procesiones, los santuarios, el sagrario donde sólo estaba permitida la entrada a los hierofantes o el modo en que, a partir de un mito agrícola, que buscaba la fertilidad y las buenas cosechas, se llegó a una serie de misterios soteriológicos sobre la vida después de la muerte ${ }^{14}$.

También los mitos de Homero y Hesíodo son incomprensibles sin la música y están relacionados con la idea de inspiración y locura divina (no olvidemos que la idea de "música" antigua era mucho más amplia que la actual, englobando no sólo la poesía y la danza, sino también la armonía espiritual del hombre y el cosmos). Como seres mitológicos, las musas, las ninfas, las sirenas, se confunden con la naturaleza: las moradas de muchas deidades son lugares concretos de Grecia, donde el resto de dioses también transitan; frente a la trascendencia del orfismo, que remarca las fronteras entre lo corporal y lo espiritual (aunque sólo sea para jugar en su límite), la inmanencia del mundo homérico resulta menos lejana. Los peligros del mar del hombre prehistórico -y mucho más que eso- reaparecen en las sirenas, donde música, posesión y locura son una misma cosa. Aedos y rapsodas (ambos, como en la poesía lírica y coral posterior, pero también en la tragedia griega, músicos expertos) no podían concebirse sin su contacto con la divinidad: poseídos por una locura divina (inducida por las Musas, a las que el poeta debe invocar), nos cuentan otra locura, la de los hombres. Esta doble faceta es evidente, por ejemplo, en el inicio de la Odisea (Canto I):

Musa, dime del hábil varón que en su largo extravío, tras haber arrastrado el alcázar sagrado de Troya, conoció las ciudades y el genio de innúmeras gentes. Muchos males pasó por las rutas marinas luchando por sí mismo y su vida y la vuelta al hogar de sus hombres pero a éstos no pudo salvarlos con todo su empeño, que en las propias locuras hallaron la muerte. ¡Insensatos! ${ }^{15}$

Aunque la memoria y la repetición resulten esenciales para aedos y rapsodas, la recitación resultante, acompañada por instrumentos musicales, se percibe como una especie de adivinación continua, reflejada en su carácter improvisatorio y facilitada por frases nemotécnicas y ritmos internos, que podían adaptar

14. Para un resumen breve pero preciso de los misterios, véase la entrada "Misterios de Eleusis" en Filoramo, Giovanni, Diccionario Akal de las Religiones. Akal, Madrid, 2001.

15. Homero, Ilíada. Odisea, ed. bilingüe de C. García Gual. Espasa, Madrid, 1999. 
a diversos públicos y geografías. Ante esta variedad, en los mitos de Hesíodo (posteriores a Homero) se afirma algo que los griegos ya habían sospechado: las musas conocen la verdad, pero también saben mentir ${ }^{16}$. Aunque los poetas están poseídos por la divinidad, ésta no promete nada al margen de su belleza (como veremos, este será el resentimiento de Platón).

La poesía lírica y coral también son incomprensibles sin la música. Lo que conservamos de ellas -por ejemplo, las odas de Píndaro- constituye una simple huella de un conjunto de poesía, música, danza y rasgos rituales que hoy nos son totalmente desconocidos. A pesar de los elementos "biográficos" (pensemos, por ejemplo, en Safo), todavía existe un importante componente religioso y ceremonial donde la unión entre dioses y hombres es vista como algo natural, y lo mismo ocurre con la comedia, la tragedia ática y sus precedentes inmediatos. En los antiguos ditirambos, de los que deriva la tragedia griega, un coro de participantes, en su mayoría mujeres, disfrazadas con pieles de animales y acompañadas por lobos y serpientes (que ceñían a sus cabezas), simulaban ser ménades y sátiros para ofrecer un violento culto al dios-niño Dionisos. Los misterios dionisíacos, celebrados sobre todo por la noche, incluían un complejo ritual orgiástico con extáticas danzas y gestos de elevado paroxismo: acompañadas del símbolo fálico del tirso, brincando y corriendo de un lado para otro con los cabellos ardiendo, embriagadas de vino, al son de una frenética música de flautas y tambores, en montes y lugares ocultos del bosque, las ménades sacrificaban animales a los que desgarraban y devoraban de manera sangrienta, comiendo su carne cruda con los ojos desorbitados, hasta entrar en trance y fundirse en una especie de locura colectiva. En Las Bacantes, donde aparecen estas descripciones, Eurípides cuenta cómo las mujeres se situaban en la sombra, descansando o durmiendo tranquilamente, haciendo salir vino, leche y miel de las rocas y las plantas, adornándose o paciendo en el lecho con otros hombres, a los que también podían devorar ${ }^{17}$.

No sólo resulta significativo que los rituales girasen en torno a las mujeres: también estaba aceptada la participación de los esclavos, mostrando con ello hasta qué punto eran cuestionados los límites de todo tipo. Dionisos se presenta siempre como un dios liberador, por analogía con el efecto del vino, el sexo y la música. El aulós adjudicado al dios, en representación de los instrumentos de viento, se consideraba lascivo por su origen oriental y, según un famoso tópico griego, por las deformaciones que causaba a sus intérpretes, a los que además impedía cantar mientras tocaban: la música ausente de poesía, según ellos, producía un frenesí irracional, frente a la serenidad de la lira de Apolo y Orfeo,

16. Hesíodo, Los trabajos y los días, La Teogonía y El escudo de Heracles, ed. de María J. Leclyse y Enrique Palau. Iberia, Barcelona, 2000.

17. Esquilo, Sófocles y Eurípides, Obras completas, coord. de Emilio Crespo. Cátedra, Madrid, 2008. 
que permitía conjugar poesía y música, y por tanto razón y pasión. Gritos, murmullos, alaridos, incluso aullidos y rugidos, más que palabras, habrían formado el núcleo de las festividades dionisíacas. No es casual que Orfeo fuera devorado por un séquito de ménades dionisíacas.

La conexión de la tragedia con los misterios dionisíacos y eleusinos, y por tanto con rituales de pasión y muerte ( $\rho \rho \gamma \omega \delta i ́ a$, en griego, es algo así como "cantar del macho cabrío", el animal sacrificado en honor a Dionisos) está probada, aunque no sepamos qué ocurría allí exactamente. Pasa lo mismo con la mántica y los oráculos, ligados a templos y ciudades concretas, como Éfira, Claros, Dodona, Dídima o Delfos, donde se realizaban distintos rituales (algunos de los cuales duraban varios días ${ }^{18}$. El caso de Apolo, que a menudo aparece como padre de Orfeo, podría aclarar el nacimiento de estas ideas, en cuyo origen se situarían los antiguos rituales de los chamanes, donde la relación entre música, danza y adivinación, por no hablar de los viajes extáticos y su conexión con las drogas, está bien documentada ${ }^{19}$. En cuanto a la comedia, que según la Poética de Aristóteles habría derivado de los coros fálicos ${ }^{20}$, también colectivos y con un importante carácter improvisatorio, se trasluce la misma relación con los elementos irracionales del cosmos, relacionados con la fertilidad a través del vino, la embriaguez y el sexo, aunque aparece una mayor presencia de rasgos carnavalescos, burlescos y cínicos, que imbuían a sus participantes en una alegría exorbitante, frente a la oscuridad báquica.

Lo que es evidente en todos estos géneros musicales es que la pérdida de identidad, la conexión con algún tipo de locura natural, animal o divina, así como el estado extático producido por la danza, la poesía y la música, jugaban un papel insustituible, por mucho que, con el paso del tiempo, se encuentren cada vez más cercanos a la escenificación de asuntos humanos, donde el público empezaba a tener una experiencia más literaria que religiosa. Esto podría explicar la manera en que los griegos adjudicaban aspectos terapéuticos y morales a la música, aunque ahora no podamos entrar en ello. La comunión con la naturaleza propia de la mitología, la confusión entre los dioses y el mundo circundante, los bosques, los ríos, los animales, constituyen la acepción fuerte de la idea de inspiración directa e inmanente (no trascendente), donde la

18. Es el caso del oráculo de Éfira, quizá el más fascinante de todos, que incluía la inmersión del consultante en el Inframundo y la comunicación con los muertos, momento que era preparado con el paso por distintas habitaciones, donde se preparaba la ingestión de drogas, baños fríos y calientes, encierro durante horas en la oscuridad, ayuno, etc., llegando a la escenificación final de los sacerdotes, cuando el muerto aparecía ante el consultante sobre un candelabro colgado del techo (véase Vandenberg, Philipp, El secreto de los oráculos, trad. de Oliver Strunk. Destino, Barcelona, 1991).

19. Véase Eliade, Mircea, Historia de las creencias y de las ideas religiosas, trad. de J. Valiente Malla. RBA, Barcelona, 2004, p. 352.

20. Aristóteles, Poética, ed. trilingüe de Valentín García Yebra. Gredos, Madrid, 2009. 
inhalación fisiológica de elementos naturales se confunde con la inspiración divina, que es cíclica y colectiva, al estar ligada a rituales. Son las acciones humanas, con sus rituales circulares y repetibles, con sus banquetes, libaciones, sacrificios e invocaciones, las que hacen posible la inspiración, que se considera casi de manera literal, como lo corrobora la ingestión de drogas ${ }^{21}$ y de otros elementos naturales: en los rituales del oráculo de Delfos (según la leyenda) se incluía la inhalación de vapores tóxicos en las cavernas ${ }^{22}$. Se trata, por tanto, de una inspiración material y ascendente, de abajo hacia arriba.

Platón hereda la actitud de fondo que subyace a los misterios: "los bienes más grandes -sostiene- nos vienen por la locura, que sin duda nos es concedida por un don divino". En el Fedro, Platón distingue cuatro tipos de locura, que podemos denominar como mántica, iniciática, poética y amorosa. Todas ellas mostrarían que "es más hermosa la locura que procede de la divinidad que la cordura, que tiene su origen en los hombres" y que "los dioses se proponen la máxima felicidad de aquellos a quienes conceden tal locura". Sobre la locura poética, sostiene lo siguiente:

La tercera forma de posesión y de locura, la que procede de las Musas, al ocupar un alma tierna y pura, la despierta y lanza a transportes báquicos que se expresan en odas y en todas las formas de la poesía, y, celebrando miles de gestas antiguas, educa a la posteridad. Pero cualquiera que, sin la locura de las Musas, accede a las puertas de la Poesía confiando en que su habilidad bastará para hacerle poeta, ése es él mismo un fracasado, de la misma manera que la poesía de los locos eclipsa a la de los sensatos (Fedro 245a).

En su teoría de la anamnesis, Platón sitúa a los poetas (amantes de la belleza) junto a los filósofos (que además aman la sabiduría). ¿Cómo es posible, entonces, que condene a los primeros en La República, lanzándose contra las grandes epopeyas de Homero y Hesíodo, que se enseñaban en las escuelas (como en Europa se enseñó después la religión cristiana)? Simplemente, Platón desconfía de su poder cognoscitivo. Los poetas hablan por inspiración divina, pero no saben lo que dicen. Los filósofos, por el contrario, pueden recordar el cosmos anterior a la caída, y no precisamente por alejarse de esa locura y posesión divina sino, más bien, por representar otra forma de locura superior a la

21. La relación del hombre con las plantas $-y$ no sólo con los animales- parece esencial para comprender el nacimiento de las religiones. El estudio de la etnobotánica y etnofarmacología, desde la obra fundacional de Richard Evans Schultes y Albert Hofmann de 1979, aclararía mucho al respecto (véase Schultes, Richard y Hofmann, Albert, Plantas de los dioses: orígenes del uso de los alucinógenos. FCE, 2012).

22. Véase, e. g., "Los oráculos" en Graves, Robert, Los mitos griegos, trad. de Esther Gómez Parro. RBA, Barcelona, 2005, pp. 198-203. 
poética, y que no por ello deja de ser poética, pero sí más cercana al verdadero amor. De hecho, la filosofía puede entenderse como un tipo de música: "la música más excelsa", según el Fedón (61a), como repite al relatar el mito de las cigarras del Fedro (259d) y que explica "la manía del filósofo" y "su delirio báquico" relatada en el Banquete (218b), donde Sócrates es comparado con el flautista Marsias, pero también con las sirenas y las víboras.

\section{De la creatio/revelatio al (in)genium}

El Cristianismo no desconoce los misterios griegos: Roma heredó las bacanales, que ganaron cada vez más adeptos, hasta que pudo prohibirlas con la llegada del cristianismo (aunque existieron persecuciones previas). Cicerón (s. I a. C.) todavía explica el furor divino de los poetas utilizando el concepto de afflatus, que recoge el significado de inspiración y entusiasmo ${ }^{23}$. La importancia de la religión griega está presente en De natura deorum, tanto como el recuerdo de la mántica y los misterios lo están en De adivinatione y De fato. Al igual que Platón, allí arremete contra ciertas formas de inspiración y busca depurar la religión de creencias supersticiosas, pero acaba cediendo a la comunión entre lo divino y lo humano, frente a los epicúreos.

Las novedades las aportará la tradición judeo-cristiana, donde inspiratio pasa a comprenderse de dos maneras opuestas: o bien como intervención divina, donde se incluirían desde las nociones de revelatio y creatio ex nihilo, hasta las leyes de la naturaleza, el poder de los reyes y la vida recta; o bien como posesión demoníaca, estudiada por la teología demonológica o la angelología y muy importante a la hora de condenar desviaciones doctrinales, discursos políticos, catástrofes naturales, enfermedades, deformaciones, comportamientos inmorales, investigaciones prohibidas, etc.

Existen innumerables interpretaciones -muchas contradictorias entre sísobre el lugar de la inspiración divina en las Escrituras. No podemos centrarnos en los matices de la teología de la inspiración: las discusiones sobre si es plenaria o no, si es subsequens o concomitans, si el hagiógrafo es mero instrumento o autor, el dogma de la inerrancia y los conflictos con la sabiduría mundana, dependen además de la historia de los textos, con sus continuas modificaciones, traducciones, fragmentos perdidos o excluidos y, desde luego, con su confusión religiosa, donde no siempre es fácil hablar de uno u otro dogma, ni siquiera de una u otra religión, a lo que finalmente se añade la historia de la Iglesia y su lucha contra determinadas herejías o cismas internos. Lo que es indudable, filosóficamente, es que el concepto de inspiratio conforma el núcleo primordial de la lógica religiosa, en la medida en que su promesa es

23. Véase Cicerón, De la adivinación, ed. bilingüe de Julio Pimentel Álvarez. Universidad Nacional Autónoma de México, México, 1988, p. 22. 
incompatible con el saber "mundano" y se define, desde las propias Escrituras, como una locura irracional o un dogma de fe contrario a la razón. Esto es así incluso cuando más se enaltece la filosofía y la razón, como se ha hecho desde San Juan y Justino Mártir, pasando por Escoto Erígena o Tomás de Aquino, y Ilegando al Aeterni Patris (1879) de León XIII, el Fides et ratio (1998) de Juan Pablo II o el Discurso de Ratisbona (2006) de Benedicto XVI.

La inspiración religiosa es siempre, y eminentemente, de arriba hacia abajo. Aunque todavía pervivan en ella elementos mitológicos -terrenales, sacrificiales, rituales, ceremoniales-, la invitación es siempre la misma: "pensad en las cosas de arriba, no en las de la tierra" (Col 3, 2). La idea de una inspiración descendente (que va del mundo celestial al terrenal) y trascendente (por la distancia que se establece entre ambos universos) es la gran aportación del cristianismo, que marcará la condena de los rituales griegos y la aparición de una dicotomía esencial entre la música divina y la mundana, la angelical y la demoníaca, la eclesiástica y la profana, incluso entre la música vocal y la instrumental. La inspiración divina ya no es material, como los vapores de las cavernas, las drogas o el sexo, sino espiritual. El primer autor clave en este punto es Clemente de Alejandría (ss. II-III), de quien hemos tomado la metáfora de la "cítara divina":

El Logos de Dios, que procede de David, pero que existía antes que él, despreció la lira y la cítara, instrumentos sin alma, y llenó de armonía, por el Espíritu Santo, este universo y el pequeño universo que es el hombre, su alma y su cuerpo. Entona un himno a Dios a través del instrumento polífono y canta con el instrumento que es el hombre: 'Pues tú eres para mí una cítara, una flauta y un templo ${ }^{\prime 24}$

La verdad sólo puede ser transmitida por el hombre si Dios le hace decirla, como rozando con los dedos sus cuerdas vocales o soplando dentro de sí. La propia vida humana proviene del soplo divino (Gn 2,7), y esto vale tanto para las Escrituras como para la Tradición. Aparte de las evidentes referencias a la inspiración bíblica (la más conocida, en 2 Tim 3, 16: "toda escritura ha sido inspirada por Dios", ratificada por el Concilio Vaticano II y la expresión "palabra de Dios"), en el Antiguo Testamento encontramos varios ejemplos, como cuando se afirma que "el Señor bajó en la nube" para poseer el espíritu de Moisés y, a través de él, enseñar el don de la profecía a setenta varones ancianos (Nm 11, 25). Esta misma imagen se aplicará, siglos después, a la traducción griega de la Biblia, al "canto gregoriano", a los dogmas católicos conectados con la infalibilidad pontificia o a las apariciones marianas (como los tres misterios de Fátima). La leyenda sobre la Septuaginta sirve de perfecta ilustración: setenta sabios judíos

24. Clemente de Alejandría, Protréptico, trad. de Ma C. Isart Hernández. Gredos, Madrid, 1994, Cap. I, pp. 37-55. 
(de ahí su nombre) la habrían escrito de forma independiente, dando como resultado setenta textos iguales, lo que mostraría hasta qué punto no fue escrita por hombres, sino por Dios. La estructura es parecida a la historia, narrada en el Antiguo Testamento, del sueño de Nabucodonosor sobre la estatua de pies de barro, olvidado por éste y revelado a Daniel de forma independiente (Dn, libro II). El tema del hombre como instrumento de Dios -que, por tanto, no necesita más instrumentos (éstos serían algo así como la "copia de la copia" en Platón)- pervive hasta hoy: en la encíclica Divino Afflante Spiritu (1943), dedicada a esta cuestión, Pío XII habla del hagiógrafo como "instrumento del Espíritu Santo".

Frente a la fugacidad de las doctrinas meramente escuchadas (que no pueden volverse a escuchar), la Biblia es "palabra de Dios", lo que asegura su carácter revelado y dado de una vez para siempre. Por eso es una religión "de libro" que redundará, sobre todo, en beneficio de la música vocal, cuya preeminencia será indiscutible hasta el Renacimiento, teniendo ya una importancia innegable en la tradición judía (muchos pasajes bíblicos son esencialmente musicales, como los Salmos y el Cantar de los Cantares). La presencia de instrumentos y danza tampoco puede negarse: sabemos que los antiguos profetas solían valerse de ellos en el momento de la profecía, cuando entraban en trance para comunicarse con la divinidad (como los profetas de Baal, que realizaban un ritual bailado y se infringían cortes en su propio cuerpo con espadas y lanzas, v. 1 Re 18, 20-40). Pero la actitud bíblica no es clara al respecto. Ps 150 nos invita a alabar a Dios con instrumentos, que otras veces se condenan (Am 5, 21-23), y aunque se nombren címbalos, trompetas, cítaras, salterios, arpas, etc., éstos se encuentran casi siempre subordinados a la expresión de la palabra o tienen un significado simbólico, no musical. Las referencias del Apocalipsis, por ejemplo, son simbólicas, como cuando se compara la voz divina con "el sonido de citaristas tocando cítaras" y se afirma que sólo los elegidos "cantaban un cántico nuevo delante del trono" $(14,2-3)$, o cuando se habla de "los vencedores de la Bestia", que aparecen "con las cítaras que Dios les había dado" $(15,2-3)$, o cuando todos cantan por el triunfo del bien (19).

Pero la leyenda más conocida sobre la inspiración musical no se encuentra en la Biblia, sino en la Tradición, y se refiere al "canto gregoriano": los cantos del actualmente denominado canto franco-romano que el Espíritu Santo, en forma de paloma, habría cantado al oído del papa Gregorio I (que en realidad vivió varios siglos antes de que se creara dicho canto en la época de Carlomagno, que es también cuando se extendió el mito de la paloma) $)^{25}$. La idea del dictado, como la del instrumento musical que hemos visto en Clemente, es muy común, y reaparecerá numerosas veces, por ejemplo en Schönberg.

25. Véase Asensio, J. Carlos, El canto gregoriano. Historia, liturgia, formas. Alianza, Madrid, 2001. 
Como consecuencia, la música es demonizada y divinizada al mismo tiempo, creándose un dualismo ontológico entre lo terrenal y lo celestial que pervivirá hasta el siglo XVII, y que situará a la música real en el último escalón de la jerarquía de las artes hasta el XIX. El ingente desarrollo de la música medieval, desde el canto gregoriano hasta la creación de las grandes misas y motetes polifónicos (muchos insuperados hasta hoy) parecería contradecir la opinión de los grandes teólogos sobre la música, desde Clemente de Alejandría (s. II d. C.) hasta la bula de Juan XXII contra el Ars Nova (s. XIV), que subordinan ésta a la religión, la liturgia y la palabra, manteniendo una enfurecida campaña contra toda música considerada no-religiosa, destinada al placer o a cualquier tipo de experiencia alejada de la fe.

Se crea una metafísica, una teología y una ética musicales donde la música considerada verdadera, la celestial, finalmente ni siquiera suena, pues el sonido real implica de manera inevitable cierto placer terrenal: incluso el canto aceptado estaría habitando el límite entre lo aceptable y lo condenable, como vemos en San Agustín. Es la música callada de San Juan de la Cruz, heredada de los pitagóricos y sistematizada por Boecio. El problema básico, a partir de ahora, será distinguir la música humana e instrumental -la armonía espiritual del hombre y la de su música, según la distinción clásica- de la divina, pues en el fondo, y debido a esta metafísica, subyace al cristianismo la tendencia a considerar que ninguna música real puede equipararse a la música divina, y que por tanto toda la música es, en el fondo, condenable. Todos los tratados de música hasta la aparición de la polifonía, a partir del segundo milenio, están dedicados a reflexiones especulativas que poco o nada tienen que ver con la música de los músicos y, cuando empiecen a tener que ver, será al precio de reducir la música a su parte teórica.

Pero la inspiración no sólo queda invertida verticalmente (arriba/abajo), dirigiéndose "contra esos que piensan que nuestra conducta está inspirada por criterios humanos" (2 Cor 10, 2), sino también horizontalmente, pues se trata de una inspiración lineal, no circular, lo que depende de la forma cristiana (milenaria, apocalíptica) de concebir el tiempo: no parte de ritos relacionados con las estaciones o con momentos circulares de la vida y el año, sino que puede ocurrir en cualquier momento pues, para Dios, todos los días son iguales (ante Él, todo lo Plural se vuelve Uno). Esto garantiza una inspiración individual incomprensible para los griegos: Dios puede aparecer ante personas distintas e inspirarles exactamente lo mismo. Esto hace que la inspiración, como la idea de gracia, adquiera un cariz arbitrario: la música será la inspirada por Dios con independencia del tiempo, de las condiciones naturales o sociales, de los rituales y las instituciones que los soporten. La condena de las drogas, incluso para fines terapéuticos (algo impensable entre los antiguos) es una prueba de ello ${ }^{26}$.

26. Escohotado, Antonio, Historia elemental de las drogas. Anagrama, Barcelona, 2011, cap. IV. 
Toda inspiración que provenga de abajo hacia arriba, o que no cumpla una función religiosa, aparecerá convertida en un momento de inspiración demoníaca, que es en realidad donde perviven el resto de funciones asignadas a la música (como el placer): el caso más claro es la condena de la música instrumental, frente a esa cítara divina cuya única expresión ha de ser la voz inspirada del profeta. El propio Clemente refleja bien este cambio. Como Justino, afirma que los griegos han caminado en algún momento hacia la verdad, al entrever algunas ideas cristianas, pero que finalmente lo han confundido todo con su música, en concreto con la tradición órfica:

A mí me parece que aquel tracio Orfeo, el de Tebas y el de Metimna, hombres tales que no eran hombres, se convirtieron en unos impostores que, con la excusa de la música, han destruido la vida; poseídos por los demonios, mediante un hábil encantamiento, llevan a la perdición ${ }^{27}$.

Es extremadamente importante que estas palabras aparezcan justo al inicio de su obra más importante, el Protréptico o Exhortación a los griegos, y ello por tres razones: primero, porque está dirigida a los griegos paganos, no a los cristianos; segundo, porque Clemente conoce en profundidad la cultura griega, en la que ha nacido y se ha cultivado; tercero, porque no estamos ante un tratado de música, sino de religión. Nadie mejor que el enemigo busca apuntar al centro y, en este sentido, que se hable de música en las primeras páginas y se desarrolle a partir de ahí todo lo demás, supone para nosotros un testimonio de gran magnitud para comprender la importancia que los griegos atribuían a la música como núcleo de su ontología y su religión. También hay un factor de tipo político o retórico que explicaría este inicio, determinado por el populismo y la superstición de los rituales mistéricos. Quizá por eso comienza ridiculizando las fábulas sobre el poder de la música en los animales, o la violencia e idolatría de los rituales: su mención al alcohol ("terminan totalmente borrachos") y al llamado furor báquico ("se agitan en loco arrebato") estarían en concordancia con ello.

Estos ataques del cristianismo primitivo, donde la música popular, lo pagano y lo profano se identifican con lo demoníaco, son muy comunes, y sólo dejan a los hombres ("los más terribles animales que hubo nunca", según Clemente) una salida: la del nuevo canto que desciende "desde lo alto de los cielos" para beneficio de "los que estábamos caídos en la tierra". La música celestial -a veces identificada con el canto eclesiástico- es divinizada con tanta fuerza como la anterior había sido demonizada, dando como resultado que la música, cada vez más institucionalizada, resulte fortalecida de una manera inexistente entre los paganos. El nuevo canto ha civilizado a los hombres, frente a la barbarie griega. Las dicotomías alto/bajo, bueno/malo, cielo/tierra, divino/diabólico son fundamentales. El

27. Clemente de Alejandría, op. cit., pp. 37-55. 
nuevo orden (el bueno, el celestial, el divino) estará configurado a partir de las teorías musicales pitagóricas, que siguen dando a la música un lugar privilegiado: "[Dios] ordenó también todo este mundo con armonía y dirigió la diferencia que había entre los elementos del mundo a una disposición de concordia, para que todo el universo fuera una armonía" ${ }^{\prime 28}$. Esto, junto a la demonización de lo popular, acentuará cada vez más la distinción entre los teóricos musicales y los verdaderos músicos, que inunda toda la Edad Media llegando -en su simplicidad- hasta Marchetus de Padua (s. XIV), aunque todavía encontremos algunas huellas medievales en el Compenium Musicae (1618) de Descartes ${ }^{29}$, con influencias que podemos rastrear hasta el siglo XX.

Esta metáfora de la armonía celestial, propia de los griegos, demuestra la increíble influencia pagana sobre los cristianos, cuyo caminar en la sombra de la historia romana les obligó a aprender sus formas de pensamiento, tanto para defenderse de los filósofos y de los misterios griegos u orientales, como para frenar la fuerza del estoicismo, el epicureísmo, el neoplatonismo, el gnosticismo, el judaísmo y otras múltiples herejías, como el montanismo, que terminarían por influirle. Tal como Roma conquistó Grecia y, al hacerlo, asimiló su cultura, los cristianos sucumbieron a múltiples aspectos del mundo greco-romano: como vemos en Clemente, la estética medieval y su teología musical no se comprende sin Pitágoras, Platón o Arístides Quintiliano, y ocurre lo mismo con la música práctica, teóricamente derivada de los modos griegos y su estética del ethos.

A pesar de todo, la desaparición de los textos y ceremonias griegas, el cierre de las escuelas de filosofía (empezando por la Academia platónica y el Liceo aristotélico, que habían permanecido más de mil años abiertos desde su inauguración), la destrucción de templos y bibliotecas, así como la presencia oriental, gnóstica y judía, hacen que la ruptura sea evidente y tengamos que esperar hasta el siglo XVII, más de mil años después, para encontrar otra forma de comprender la locura y la inspiración. Las consecuencias son obvias. Entre los medievales, ha desaparecido el contacto con los dioses como lugares concretos del mundo y manifestaciones especiales de la naturaleza. El concepto de Dios de los gnósticos (siglos II y III) encaja en parte con la dicotomía cristiana, que reaparecerá al final de la Edad Media con el Nominalismo, y luego con el Protestantismo: un Dios todopoderoso resulta demasiado perfecto e inabarcable como para identificarse sin más con el Dios del Antiguo Testamento o el humanamente cognoscible.

Dios no puede ser previsible o apresable: ni siquiera el orden mundano, creado por Él pero al mismo tiempo nacido del pecado (esta es una contradicción típica de muchas religiones), puede estar a la altura. La oposición entre la natu-

28. Ib.

29. Descartes, René, Compendio de Música, trad. de Primitiva Flores y Carmen Gallardo. Tecnos, Madrid, 1992. 
raleza y Dios, entre un demiurgo Anti-Dios y un Dios verdadero, y el consiguiente desprecio por la materia o la carne, subyace incluso al catolicismo, aunque sólo sea como una tendencia inconfesada. El Pecado Original, el Apocalipsis, el Fin de los Tiempos, el Diablo (un ángel caído), el Anticristo, el Infierno, el "lago ardiente de fuego y azufre, que es la segunda muerte" (Ap 21, 6), son ideas que existen desde los primeros siglos del cristianismo, en parte por la persecución que sufrieron sus adeptos durante varios siglos, y que implican necesariamente -como la posterior De civitate Dei contra paganos de Agustín, cuya tradición arranca del propio Cristo ("mi reino no es de este mundo", Jn 18, 36) - una demarcación dicotómica y dualista ${ }^{30}$.

Al suponer un dios trascendente y espiritual, incompatible con un mundo desbordante de pecados, que aborrece la carne y que es lo opuesto de la animalidad -por mucho que los dogmas de la Trinidad y la Transubstanciación pretendan remediarlo-, la inspiración se convierte en un arma de doble filo: si, por una parte, permite la exaltación de un canto determinado, por otra provoca una actitud condenatoria ante el resto de fenómenos musicales, imposibilitando la reflexión sobre la música realmente existente y agotando todos los esfuerzos teóricos en una supuesta música eterna que, de hecho, contradice la rica realidad musical del momento. La música no revelada -la no cantada al oído de Gregorio- procede del Diablo y tiende a ser considerada como atea: la misma acusación que los primeros heresiólogos vertieron sobre los gnósticos y los filósofos. Los exorcismos, la cacería de brujas, el trato dado a niños deformes o con problemas mentales, irían en esta misma dirección.

Frente a la locura del mundo, solamente puede oponerse la locura divina de los santos y los que tienen fe. Clemente contrapone, al denostado Orfeo, el nuevo canto cristiano, hasta el punto de afirmar que "los muertos, que no tenían parte de esta vida verdadera, sólo por ser discípulos del canto, han resucitado de nuevo" ${ }^{\prime 31}$. Esta cara de la dicotomía monoteísta encaja con la propia locura de la crucifixión. En sus cartas a los corintios, Pablo de Tarso no solamente afirma que la sabiduría del mundo es necedad a ojos de Dios y que todo esfuerzo por conocer, al margen de la fe y la revelación, es vano, sino también que Dios ha venido al mundo para destruir esa sabiduría. La justificación se hace desde las coordenadas que hemos tratado hasta ahora, donde la locura del diablo puede ser contrapuesta a la locura de Dios, que implica la locura de los creyentes ante un mensaje incomprensible, pero verdadero: "Dios ha querido salvar a los creyentes por la locura del mensaje que predicamos". Esto supone un ataque contra los filósofos, pero también contra los judíos, que a su vez ven como locura dicho mensaje: "nosotros predicamos a un Cristo crucificado, que es escán-

30. Véase Carozzi, Claude, Visiones apocalípticas en la Edad Media. El fin del mundo y la salvación del alma, trad. de J. Antonio Padilla Villate. Siglo XXI, Madrid, 2000.

31. Clemente de Alejandría, Ib. 
dalo para los judíos y locura para los paganos" (1 Cor 1, 21-25). Tertuliano -uno de los padres de la Iglesia más influyentes de los siglos II y III- daría forma a esta actitud con su famoso apotegma: creemos porque es absurdo.

Si tomamos como un paso previo, todavía tejido con hilos cristianos, la forma de amor cortés de los trovadores o, posteriormente, de Petrarca, donde la mujer aparece como Musa inspiradora (la prueba estaría en el escrúpulo, que Petrarca comparte con Agustín -al que leía con devoción-, con que se advierte la extralimitación del amor mundano y sensual, poético y musical, que sólo debería pertenecer a Dios ${ }^{32}$ ) tenemos que esperar hasta el siglo XVII para encontrar una teoría del arte realmente novedosa: cuando aparecen los conceptos de "ingenio" y, después, de "genio". Por primera vez, se entenderá que es el hombre quien "crea": un mérito que, hasta entonces, se había dado en exclusiva a Dios y que los griegos tampoco contemplaron (no sólo por el ex nihilo nihil fit, sino también por su concepción cíclica del tiempo -presente hasta Platón-, que les hace relacionar la inspiración con estados repetibles o ritualizados).

La idea de inspiración, tal como había sido entendida hasta ahora, sufre un duro golpe, al contraponerse a ella estudios de tipo médico o psicológico que pretenden encontrar la explicación de la creatividad en la naturaleza humana (el "talento" de los artistas, es decir, el peso), junto a otros estudios de tipo históricofilológico que, sin duda, juegan un papel desmitificador subterráneo: si el providencionalismo del derecho divino de los reyes culmina con la decapitación de Carlos I en 1649, el Tractatus theologico-politicus (1670) de Spinoza negará más tarde, quizá con la misma fuerza, el carácter inspirado de las propias Escrituras ${ }^{33}$. Se produce una secularización de ideas religiosas, una nueva legitimidad marcada por una profunda crisis, el nacimiento de la sociedad capitalista, la ciencia y la filosofía moderna ${ }^{34}$, y la reaparición de nociones antiguas, como la idea de

32. En el caso de San Agustín, son célebres sus palabras: "peco (...) cuando el tono y el canto me mueve más que las cosas que se cantan; y entonces más quisiera no oír cantar" (Confesiones, Sarpe, Madrid, 1983, cap. XXXIII); en cuanto a Petrarca, véase el tercer libro del Secretum, donde se afirma que "nada lleva a un hombre a olvidar o despreciar a Dios tanto como el amor por las cosas temporales, y sobre todo esta pasión que llamamos amor, y a la cual, en la más grande de las blasfemias, damos incluso el nombre de Dios, sin duda para arrojar un velo celestial sobre nuestras locuras humanas y pretextar la inspiración divina cuando queremos cometer una enorme transgresión" (cit. en Singer, Irving, La naturaleza del amor: cortesano y romántico. Siglo XXI, Madrid, 1999, p. 157).

33. Aunque Spinoza sigue dando un lugar a la revelación bíblica, ésta se mueve ya en un terreno meramente práctico, marcado por la obediencia (que apela de forma abstracta a la existencia de Dios y a la obligatoriedad de la justicia y la caridad), sin decir absolutamente nada sobre "Ios secretos de la filosofía" (TTP, Cap. XIII, p. 151). La Biblia estaría dirigida a aquellos hombres ignorantes que, no siendo capaces de guiarse por los consejos de la razón, al menos así obedecen los mandatos divinos por la autoridad de las Escrituras (Cap. XV, p. 167).

34. Véase Blumenberg, Hans, La legitimación de la Edad Moderna, trad. de Pedro Madrigal. Pre-textos, Valencia, 2008. 
locura "médica". En España, la obra de Juan Huarte de San Juan, Examen de ingenios para las ciencias, donde se muestra la diferencia de habilidades que hay en los hombres, y el género de letras que a cada uno corresponde en particular (1575/1594), hace revivir la antigua sospecha aristotélica, según la cual los artistas tienen un "ingenio" específico ${ }^{35}$, y también se produce el Gran Encierro (la creación de los primeros manicomios) ${ }^{36}$. Don Quijote (1605-15), contemporáneo de L'Orfeo (1607), responde perfectamente a esta nueva situación: no es casual que el nacimiento de la novela, junto al teatro de Shakespeare o la pintura de Caravaggio, esté unido a figuras enloquecidas o melancólicas. El propio adjetivo de "ingenioso" aplicado al Caballero de la Triste Figura en el título de la obra tiene seguramente una connotación médica. También trataban sobre el "ingenio" (a veces traducido por "espíritu") las Regulae ad directionem ingenii de Descartes y el Agudeza y arte de ingenio (1648) de Baltasar Gracián, donde la polisemia y la riqueza del concepto se hacen cada vez más evidentes. En la segunda mitad del siglo, en parte llevado por las reflexiones españolas, también Spinoza acogerá las pasiones bajo el concepto de ingenium, que le permitió hacerse cargo de la diversidad de individuos, y por tanto de su corporalidad, garantizando la persuasión y construcción de la república ${ }^{37}$.

En la misma época aparece la "doctrina de los afectos" (Affektenlehre) $)^{38}$ -concepto también central en la Ethica (1661-75) de Spinoza-, una teoría retórica conectada con el nacimiento del dramatismo barroco, la tonalidad y la armonía, que se consolidará durante el siglo XVIII y que inundará todos los géneros, especialmente la ópera, pero también la música instrumental, donde la narración, la emoción y los sentimientos se elevan sobre la teología musical, dando más importancia a la oratoria y la influencia sobre el auditorio que a la supuesta inspiración divina del arte (ya el concepto de ingenium, en el Renacimiento, se había utilizado en un sentido humorístico, referido a la capacidad del artesano para "entretener" a los invitados)" $)^{39}$, aunque esta nueva con-

35. Véase Huarte De San Juan, Juan, Examen de ingenios para las ciencias, ed. de Guillermo Serés. Círculo de Lectores, Barcelona, 1996, donde se afirma que "si Dios o Naturaleza no hacen al hombre poeta, poco aprovecha enseñarle con preceptos y reglas cómo ha de metrificar", de modo que "si el que tiene naturaleza acomodada para ella se da a componer versos, los hace con gran perfección, y si no, para siempre es mal poeta" (Cap. VIII., p. 228). Unas páginas después asegura que los poetas -y dedica un fragmento a los músicos- están naturalmente tan dotados de imaginación como faltos de entendimiento, lo cual puede explicarse médicamente.

36. Véase Foucault, Michel, Historia de la Locura, FCE, México, 1999.

37. Moreau, Pierre-François, "Spinoza y Huarte de San Juan" en Atilano Domínguez (ed.), Spinoza y España. Actas del congreso internacional sobre relaciones entre Spinoza y España. Colección Estudios, Universidad de Castilla-La Mancha, Cuenca, 1992, pp. 155-163.

38. Véase "La doctrina de los afectos" en Walter Hill, John, La música barroca. Música en Europa occidental, 1580-1750, trad. de Andrea Giráldez. Akal, Madrid, 2010, pp. 400-406.

39. Véase "Teoría del Ingenio" en Burckhardt, Jacob, La cultura del Renacimiento en Italia, trad. de Teresa Blanco, Fernando Bouza y Juan Barja. RBA, Barcelona, 2005, p. 206. 
figuración dependa todavía de elementos mágicos ${ }^{40}$. Dios se ha diluido en el ingenio del artista y su capacidad para crear una obra musical capaz de influir en los oyentes.

El cariz metafísico de la idea de inspiración, en todo caso, no ha desaparecido, ni lo hará con el nacimiento de la Estética, a partir de 1750: en plena llustración, el famoso mito creado en torno a Mozart (1756-1791) podría servirnos de ejemplo. Similar al nuevo concepto de "genio" que inundará todas las reflexiones artísticas hasta el siglo XX -otra palabra de origen religioso, entendida como "deidad tutelar", por su raíz yévos, referido a la "raza", la "familia" o la ciudad, aunque también a las acciones de "engendrar", "nacer" o "crear"-, Mozart escribiría sus obras "como si fuera un producto de la mera naturaleza"41, por decirlo con las palabras contemporáneas de la Kritik der Urteilskraft (1790) de Kant, es decir: tal como al árbol le crecen las hojas, el músico escribiría sobre papel pautado sinfonías enteras, como si estuviesen ya terminadas en su cabeza antes de comenzarat. Es fácil ver que esto presupone la idea de "obra", que tampoco había existido antes del siglo XVIII y que hace surgir en esta época, por ejemplo, la idea de los derechos de autor.

Otra anécdota sobre Mozart, en sus primeros viajes como niño virtuoso, retomaba el tema del pacto con el Diablo: el público, en presencia de uno de sus conciertos de piano en Nápoles, quedó tan asombrado por las capacidades del pequeño que le pidieron quitarse el anillo que llevaba, suponiendo que era el garante de un pacto infernal ${ }^{43}$. La idea de espontaneidad es esencial en ambos casos: en esto no habrá ruptura con el siglo XIX, que alentará este mito sobre el joven salzburgués y dará a los nuevos compositores el aura de ese poder otrora limitado a Dios: ahora, los "genios" crean "obras" y son "autores". Bajo la aparente simplicidad de las sinfonías clásicas, esta idea de espontaneidad (como el "desinterés" kantiano) oculta el momento del trabajo, más presente en el siglo anterior, lo que sin duda refleja el dogma de la época: el orden mecánico del cosmos newtoniano donde todo es armonía, incluido el sujeto al que se supone puro, constituyente y libre. Ante esta metafísica a un mismo tiempo

40. En Tomlinson, Gary, Canto metafísico. Un ensayo sobre la ópera, trad. de T. Paul Silles. Idea Books, Barcelona, 2001, se detalla el papel de la ópera en la construcción del mundo oculto, inaccesible, extravagante, irreal e irracional propio de cada época.

41. Kant, Immanuel, Crítica del juicio, trad. de Manuel García Morente. Austral, Madrid, 2007, p. 248.

42. Este mito llega hasta el siglo XX: véase, e. g., Petit, Pierre, Mozart o la Música Instantánea. Rialp, Madrid, 1993, cuando escribe que "esta sinfonía [de Linz] surgió ya completa directamente de la cabeza del músico, como Minerva de la de Júpiter" (p. 12). Aunque, sin duda, es sorprendente que la compusiera en cuatro días, la musicología ha demostrado ya el concienzudo trabajo de Mozart, sus correcciones, el material prestado de otros compositores (evidente, e. g., en el Réquiem), etc.

43. Petit, Pierre, op. cit., p. 98. 
idealista y subjetivista, individualista y psicologista, la idea de inspiración se hace cada vez más confusa.

\section{De la patología romántica al inconsciente}

El industrial siglo XIX, plagado de fábricas y locomotoras, también ocultará la idea del trabajo, pero esta vez dando al artista un poder aún superior: el de componer obras de una dificultad sobrehumana, no como extensión de la potencia normal de la naturaleza, sino como reflejo de una omnipotencia sobrenatural, en muchos casos demoníaca, producto del pacto con el Diablo. El Don Giovanni (1787) de Mozart había anticipado esta tendencia sombría que se resolverá, con todas sus consecuencias, en la línea que va del Faust (1832) de Goethe al Doktor Faustus (1947) de Thomas Mann.

Los románticos lo mezclan todo y son contradictorios a propósito, porque sienten que el mundo lo es. Amor, castidad, sadismo, ascetismo, fusión con la naturaleza, individualismo, nacionalismo, populismo, catolicismo, ateísmo. En la inspiración se esconde ahora un elemento que lo funde todo, haciendo de esta idea algo aún más complejo e impreciso de lo que había sido hasta entonces: la locura patológica. La tradición, como hemos visto, se remonta a Aristóteles, pero esta vez la locura está atravesada por elementos mágicos, mitológicos, religiosos, apocalípticos. El artista está loco y, por estarlo, es el más cuerdo de todos: tiene un contacto especial con la Naturaleza, con el pueblo, con la historia, con el mundo onírico, con Dios. La locura es un signo de lucidez: agudiza los sentidos, sobreexcita los nervios y nos hace prestar atención a los detalles. Don Quijote, bajo la mirada romántica, es capaz de ver lo extraordinario que se esconde tras lo cotidiano; el sonámbulo, entregado a la oscuridad del sueño, sabe más que el despierto; el poeta, más que el científico (Hölderlin). El foco central se dirige al individuo creador, al genio ilustrado ahora enloquecido, más que al elemento externo de la inspiración. La originalidad no era propia del creador ingenioso, ni siquiera del genio clásico, pero sí lo será del romántico: en plena era revolucionaria, éste ya no crea como si fuera naturaleza mecánica y armónica, sino, más bien, como si fuera él mismo un dios delirante, capaz de reunir dentro de sí todas las fuerzas del universo, creando y destruyendo al mismo tiempo, sin importar exactamente qué. Es el propio juego de creación y destrucción lo que se saborea, la forma: estamos ante el absolutismo de la música y el esteticismo del arte por el arte $^{44}$. El creador es una especie de Simón el Estilita con poderes ilimitados: un asceta que, a pesar de su soledad e ignorancia, lo engendra todo, en un derroche de fuerza autosuficiente que no necesita de justificación ni finalidad. Schopenhauer habla del "olvido de la propia persona" producido cuando el artista crea,

44. Véase Dahlhaus, Carl, La idea de la música absoluta, trad. de Ramón Barce Benito. Idea Books, Barcelona, 1999. 
Ilamando a esto Begeisterung, que recoge literalmente la idea de "entusiasmo" o "endiosamiento", traducida como "inspiración", donde "el objeto es captado con toda claridad según su esencia más íntima" ${ }^{\prime 4}$, aunque esta misma clarividencia haga que el artista, cuando contempla la sordidez del mundo cotidiano, se sumerja en la melancolía, como Hamlet.

A los románticos debemos la asimilación de que lo irracional precede siempre a lo racional. De Hoffmann a Schopenhauer, llegando a Nietzsche, la música será el arte romántico por excelencia, capaz de expresar la esencia creativa del mundo, y por tanto la más conectada con la locura y la originalidad ${ }^{46}$ : en ella, el hombre siente el caos de la sinrazón, una voluntad de poder ajena a todo raciocinio, aunque con ello acceda a la máxima claridad. El carácter religioso, por paradójico que sea, siempre termina apareciendo. Schopenhauer, después de haber asegurado la preeminencia de la música instrumental, hará de la música eclesiástica "la mejor para alcanzar una intuición de la esencia de la música $^{\prime \prime 7}$ : los polos opuestos tienden a reconciliarse, como en Hoffmann, que opinaba exactamente lo $\mathrm{mismo}^{48}$. El hombre está solo ante un mundo metamorfósico, desbordante de creatividad, y a pesar de todo tiene la capacidad de saltar al vacío de ese abismo y fundirse con él. El propio mundo es un caos, en el que todo empieza y acaba al mismo tiempo: el inicio del nihilismo ante el cual, finalmente, sólo podrá oponerse el arte. En una extraña inversión de la mística pitagórica, la música nos enseña el caos inefable del mundo, pero al mismo tiempo nos compensa con la ofrenda salvadora del juego. Perdidos, sólo nos queda bailar ante nuestra perdición: la imaginación, el arte, la creación, tan vacía de sentido como el mundo, cuya sinrazón no oculta, puede por eso mismo oponer una carcajada ante el espantoso delirio del universo ${ }^{49}$.

Esto podría explicar, en parte, el fenómeno de la lisztmanía ( $\mu a v i ́ a$ es como los griegos llaman a la locura) así como el enaltecimiento romántico de Cho-

45. Schopenhauer, Arthur, Lecciones sobre metafísica de lo bello, trad. de Manuel Pérez Cornejo. Universidad de Valencia, Valencia, 2004, p. 123.

46. Hamilton, John T., Music, madness and the unworking of language. Columbia University Press, New York, 2008.

47. Schopenhauer, op. cit., p. 303.

48. Véase "Música religiosa, antigua y moderna" (1814) de Hoffmann, quien también hacía de la música instrumental la música verdaderamente romántica, recogido en Benedetto, Renato di, El siglo XIX. Primera parte, trad. de Carlos Fernández. Turner, Madrid, 1987, donde afirma que "en su esencia más característica e interior, la música es, pues, como habíamos dicho, culto religioso, y su origen ha de buscarse únicamente en la religión y en la Iglesia" (p. 169).

49. Así en Nietzche, para quien "el arte es la tarea suprema y la actividad propiamente metafísica de esta vida" (Nietzsche, Friedrich, El nacimiento de la tragedia, trad. de Andrés Sánchez Pascual. Alianza, Madrid, 2010, p. 40) porque "el mundo -según dirá en su obra póstuma- puede considerarse como una obra de arte que se engendra a sí misma" (Nietzsche, Friedrich, La voluntad de poder, trad. de Aníbal Froufe. Edaf, Madrid, 2008, \&790). 
pin, pero, sobre todo, estaría en la base del wagnerismo, de la construcción del Templo de Wagner (el teatro de Bayreuth) y la evidente locura de los acólitos wagnerianos, que es sin duda el mayor fenómeno social de todo el siglo XIX en el ámbito de la denominada "religión del arte" (Kunstreligion). La inspiración guarda ahora una estrecha relación con la doctrina hegeliana. El genio creador forma parte de un proceso histórico que refleja el autoconocimiento de Dios: sólo siendo poseído por su curso y reflejando su carácter absoluto -encarnado en un pueblo y una nación determinada-, el artista puede crear una obra digna del futuro ${ }^{50}$. La continuidad que Wagner encontraba entre sus dramas y las sinfonías de Beethoven, así como su anti-semitismo, es análoga, en su ceguera, al derecho que Hegel otorga al Estado prusiano (o al Estado real que represente en cada momento el último peldaño de la Historia Universal) para dominar al resto de pueblos ${ }^{51}$, lo que nos muestra la cara más negativa y peligrosa de la idea de inspiración. Desde Bartók hasta Sibelius, todos los nacionalismos del siglo XIX, y también del XX, donde un imaginario espíritu del pueblo (Volkgeist), de la época (Zeitgeist) o del mundo (Weltgeist) -o quizá los tres a la vez- insuflaría con su soplo divino a los músicos y héroes nacionales la esencia de su verdadero ser, parten de esta idea ${ }^{52}$, aunque sea secularizada, que en el fondo no se comprende sin la forma kantiana de ver el arte como naturaleza (en el caso de España, lo vemos en su musicología desde Barbieri y Pedrell hasta LópezCalo) $)^{53}$. Esta es una teoría que, pasando por Marx y eliminando la meta dialéctico-positiva, llega hasta Theodor W. Adorno (1903-1969).

La relación entre música romántica y locura se puede abordar también desde un plano psicológico. Los pensamientos suicidas de Beethoven, el bipolarismo de

50. Wagner, Richard, La obra de arte del futuro, trad. de J.B. Llinares Chover y F. López Martín. Servei de Publicacions, Universitat de Valencia, Valencia, 2000.

51. Aquí, la determinación sobre si hablamos del Estado prusiano o cualquier otro imaginado por Hegel es irrelevante. Sea el Estado que sea el que represente el desarrollo del espíritu universal, ése debe dominar al resto de pueblos, como es evidente en Enciclopedia de las ciencias filosóficas, trad. de Ramón Valls Plana, Alianza, Madrid, 2008, donde Hegel sostiene, e. g., que "la autoconciencia de un pueblo particular es portadora de aquel peldaño de desarrollo del espíritu universal que se ha logrado hasta ese momento en la existencia de este mismo espíritu, y es la realidad efectiva y objetiva en la que el espíritu universal deposita su voluntad", a lo que añade: "contra esa voluntad absoluta, la voluntad de los otros espíritus particulares de un pueblo no tienen derecho; aquel pueblo es el dominador del mundo" (\& 550).

52. Véase Hegel, G.W.F., Lecciones sobre la filosofía de la historia, trad. de José Gaos. Círculo de Lectores, Barcelona, 1995, donde encontramos afirmaciones como la siguiente: "Lo único que puede reconciliar al espíritu con la historia universal y la realidad es el conocimiento de que cuanto ha sucedido y sucede todos los días no sólo proviene de Dios y no sólo no sucede sin Dios, sino que es esencialmente la obra de Dios mismo" (p. 890).

53. Véase Ros-Fábregas, Emilio, "Historiografía de la música en las catedrales españolas: nacionalismo y positivismo en la investigación musicológica". Codex XXI, Revista de la comunicación musical 1, pp. 68-135. 
Rossini, el intento de suicidio de Schumann, con su posterior locura e internamiento, los traumas que causó a Tchaikovski la ocultación de su homosexualidad, la sinestesia de Scriabin y Schönberg, podrían servirnos a modo de ejemplo, pero sobre todo nos interesaría recordar el ánimo casi místico con que sus contemporáneos recibieron estas patologías, así como su incapacidad para explicar por qué algunos artistas no estaban "locos" (en el sentido en que ellos lo entendían), ni todos los locos eran artistas, algo que heredó en parte el siglo XX, especialmente en el ámbito surrealista de entreguerras, muy influido por el psicoanálisis y sus elucubraciones sobre el inconsciente. Los esfuerzos del padre de la criminología, Cesare Lombroso (1835-1909), por reunir obras artísticas realizadas por enfermos mentales de asilos y manicomios, así como su asociación entre locura y criminalidad $^{54}$, estaría en esta línea del arte como patología, que llega hasta la famosa Colección de Hans Prinzhorn (1886-1933) ${ }^{55}$ y el movimiento del Art Brut. En un plano similar, mezclada con la ideología nacionalista del siglo anterior, se encuentra la política propagandística de Joseph Goebbels sobre el "arte degenerado" (Entartete Kunst), igualmente presente en la España de Franco, la Italia de Mussolini o la Rusia de Stalin. Es fácil ver hasta qué punto el empeño por tomar a los artistas por enfermos puede ser ideológico.

Aunque el psicoanálisis de Freud no deja de ser tradicional al considerar la idea de inspiración (la obra procedería espontáneamente de la sublimación del chorro de energía sexual interna e inconsciente del artista), pudo servir de antídoto contra la conexión arte-enfermedad, quizá paradójicamente, al suponer a partir de 1915, con su hipótesis de la "fantasía originaria" (Urphantasien), que todos estamos locos a nuestra manera, como se verá especialmente a partir de Die Zukunft einer Illusion (1927) y Das Unbehagen in der Kultur (1930). ¿Hasta qué punto, entonces, cuando Ilamamos loco a alguien, sólo hacemos notar nuestra distancia con él, lo excluimos y evitamos conocerlo en serio? La famosa risa de la Tracia ante la caída de Tales o, por citar su opuesto, la sonrisa permanente del viejo Demócrito, a quien todos tomaban por loco cuando, en realidad, era el hombre más cuerdo (y por eso reía), o el caso relatado por Jenofonte sobre Sócrates, cuya fisionomía "viciosa" debía tomarse más como una muestra de su autodominio que como una prueba de su naturaleza oscura, apuntarían en esta dirección.

Schönberg es sin duda la bisagra que media entre la concepción decimonónica del genio enfermo y la pérdida del aura del siglo XX. Sus obras de principios de siglo todavía se alimentan de la lógica wagneriana, como queda

54. Véase Peset, Jose Luis y Peset, Mariano, Lombroso y la Escuela Positivista Italiana. CSIC, Madrid, 1975. Uno de sus estudios se titula, precisamente, Genio y Locura (1864).

55. Véase Prinzhorn, Hans, Expresiones de la locura: El arte de los enfermos mentales, trad. de María Condor. Cátedra, Madrid, 2012, obra publicada en 1922 con ilustraciones de su colección. 
reflejado en su Harmonielehre (1911), dedicado a Mahler. Allí repite una y otra vez el papel del inconsciente en el momento de la creación, justo cuando está creando sus obras neo-románticas y expresionistas. La inspiración, ya trastocada por el pensamiento romántico, se hace un concepto cada vez más ambiguo. Es típico del ocultismo y el espiritismo de finales del siglo XIX y principios del $X X$, pero también de la recién nacida psicología experimental y de la teosofía, hacer de lo "espiritual" algo "material": unir el mundo de los vivos y de los muertos, superando la escisión cristiana e ilustrada para llevar la ciencia al mundo de los espíritus. Los dogmas apocalípticos, también muy numerosos en esa época (como se refleja en Hegel), en época de industrialización, revoluciones y nuevas crisis $^{56}$, llevan a la exaltación de ciertos individuos como mártires o salvadores prometeicos, garantes "espirituales" de un nuevo cambio "material" cercano al fin de los tiempos y, por tanto, al inicio de los verdaderos tiempos (como la "música del futuro" de Wagner). El músico genial aparece entonces como un salvador mesiánico, un loco visionario, un continuador de la historia universal que se refleja, de manera instintiva, en su inconsciente: el artista, sostenía Schönberg en su Tratado, expresa "la esencia de la humanidad". Por eso su obra quiere ser revulsiva y reveladora. Su relación con Kandinsky se mueve en estas coordenadas: también en 1911, en la primera carta que le dirige (como respuesta a una anterior del pintor) sostiene que "el arte pertenece al inconsciente ${ }^{\prime \prime 57}$. La idea de inspiración tiene aquí una presencia innegable, ligada a consideraciones sobre la subjetividad de origen decimonónico:

La creación del artista es instintiva. La consciencia tiene en ella poco influjo. Él siente como si le dictasen lo que hace. Como si hiciera sólo lo que procede de una fuerza interior cuyas leyes no conoce. Es el ejecutor de una voluntad oculta, de su instinto, de su inconsciente. No sabe si se trata de algo nuevo o viejo, bueno o malo, bello o feo. Siente sólo el impulso al que debe obedecer ${ }^{58}$.

Podríamos poner numerosos ejemplos más. El compositor Jonathan Harvey, recientemente fallecido, publicó en 1999 su Music and Inspiration, resultado de su tesis doctoral de 1964, donde recoge numerosas citas de grandes compositores del siglo XX. Esperaba, de manera un tanto ingenua, aunque reconociendo las limitaciones de un enfoque como el suyo, dar con ello una respuesta atemporal al problema de la inspiración musical. En su obra, queda demostrada la asombrosa presencia de esta idea y la confusa manera en que los músicos

56. Véase Linse, Ulrich, Videntes y milagreros. La búsqueda de la salvación en la era de la industrialización, trad. de Rosa Pilar Blanco. Siglo XXI, Madrid, 2002.

57. Schönberg, Arnold y Kandinsky, Wassily, Cartas, cuadros y documentos de un encuentro extraordinario, trad. de Adriana Hochleitner. Alianza, Madrid, 1987, p. 18.

58. Schönberg, Arnold, Tratado de Armonía. Real Musical, Madrid, 1979, pp. 491-495. 
relatan, en momentos y lugares distintos, ese sentimiento de arrebato y descontrol que les hace ser cauces más que sujetos dominadores de su proceso creativo: ideas místicas, apelaciones a la religión, a la mitología, al inconsciente, a las matemáticas, al universo, se hallan generalmente envueltas en un ingenuo psicologismo -el inaugurado en el siglo XIX-.

Se trata de un trabajo valioso, aunque su autor no es consciente de la limitación con que analiza la idea de inspiración, pues todos ellos hacen referencia a un proceso creativo de carácter individual y privado -por mucho que tengan en cuenta los elementos externos de la creación, como la importancia del público o sus ideales-, sin atender a nociones distintas y anteriores a la idea decimonónica de autor, como la noción ritual, colectiva, circular, horizontal, inmanente, material y ascendente, o la noción teológica, lineal, vertical, trascendente, espiritual y descendente que hemos visto, que además están mezcladas en la realidad, dando lugar a numerosas posiciones distintas e intermedias, que son las que dieron su verdadera fuerza histórica a la idea de inspiración. Esto impide a Harvey realizar una crítica exhaustiva sobre dicha idea, sacando a la luz hasta qué punto es destructivo para ella que el canto gregoriano sea anterior a Gregorio I, que Mozart no compusiera "espontáneamente", que Beethoven no tuviera nada de Prometeo, ni Wagner de "raza aria", ni la música de Tchaikovski de "homosexual", ni Brahms de "enfermo", o que el psicologismo del inconsciente sea inútil para entender la aportación de Schönberg. Como mínimo, se olvida aquí la importancia de la historia, el trabajo, la educación y las instituciones.

A pesar de ello, la obra de Harvey nos sirve como antología de textos, y nos remitimos a ella para demostrar aquello en lo que no podemos detenernos ahora. Si hubiera una obra como esta por cada siglo de nuestra tradición, sin duda habríamos podido profundizar mejor en diversos aspectos. Esa tarea está por hacer.

\section{La inspiración: en busca del "aura" perdida}

Uno no imagina un caso de histeria colectiva -ni siquiera individual- ante un cuadro de Rafael, una catedral gótica o una novela de Joyce. Algo tan común y sencillo en la música desde los antiguos rituales, sólo puede ser igualado de manera excepcional por el resto de fenómenos artísticos, como el caso de los suicidios colectivos que surgieron tras la publicación del Werther de Goethe o el "síndrome" de Stendhal ante la Basílica de la Santa Cruz (Florencia): e incluso aquí notamos que, o bien los actos colectivos son posteriores a la "vivencia" de la obra (la lectura), o bien se trata de un fenómeno individual.

En música, sin embargo, la pérdida de sí (colectiva o no) es casi lo habitual. En toda fiesta, mascarada, carnaval, se requiere una función de sincronización temporal y transporte espacial que el resto de artes no puede cumplir. No es casualidad que ningún arte reciba tantas críticas como la música por su poder diabólico durante la Edad Media. Bastaría con acudir hoy a un concierto de Rock, donde las convulsiones de los cantantes sobre el escenario, el éxtasis 
continuo del público, los gritos de sus "fans" (otro concepto de origen religioso), la puesta al límite del oído durante unas horas, o la búsqueda de un estado de embriaguez y furor colectivo, es casi un presupuesto obligado. Una situación radical se da en la música techno, donde la presencia masiva de drogas llega a hacer de muchos de sus participantes una especie de moscas hiperactivas que, chocando ad infinitum contra el mismo cristal, dejan de escuchar y se entregan a su propio movimiento mecánico: la repetición ofuscada de ritmos, donde todo cambio se funde en un conjunto monótono y machacón, es una imagen de su estado de obnubilación, como se reconoce claramente en el género gabber, que ejerce una violencia casi insufrible sobre el oído a través de golpes de bombo distorsionados y a un ritmo frenético. Es obvio, por lo tanto, que la idea de inspiración, esa búsqueda de posesión divina de Platón que ahora es una simple locura humana, está presente en algunos conciertos de música popular, donde los elementos rituales siguen ejerciendo una fuerza imparable ${ }^{59}$, y lo mismo sucede en otras partes del mundo.

Pero ha ocurrido algo importante, sobre todo durante la segunda mitad del siglo XX, que ha alterado esta conexión en la música "clásica". Se trata de un cambio que está relacionado con el "Estado de Bienestar", el afianzamiento de la burguesía y las democracias contemporáneas, y concretamente con las nuevas formas de hacer arte y difundirlo, como la fotografía, la radio, la televisión y, sobre todo, el cine, que es hoy el arte más extendido, junto a la música popular. Podríamos preguntarnos si el cine, tal y como está constituido hoy, es un lugar adecuado para aquélla antigua pérdida de identidad. Si bien ha sustituido al resto de artes en muchos aspectos, parece obvio que no tiene aquél poder festivo, inmediato, colectivo, irracional, que siempre se le ha adjudicado a la música: los espectadores de cine están quietos, incomunicados, y las obras no se conciben como acciones únicas, sino como productos repetibles de un trabajo técnico en sí mismo irrepetible.

En la tradición musical, esta situación ha coincidido con una vuelta de los artistas y compositores a elementos improvisados, rituales y colectivos, que algunos quisieron re-aprender en Oriente y que son comunes al origen de nuestra tradición. Desde las performances y los happenings hasta la música aleatoria o indeterminada, la configuración mística y pseudo-religiosa de la música contemporánea no puede negarse. Pero esta música o estas acciones no han conseguido resucitar aquel antiguo poder transfigurador e irrepetible, sino que han sido presididas por el haz del objetivismo del siglo XX, al menos desde el punto de vista del oyente.

59. Sobre la noción de "ritual" más allá de su sentido religioso, tal y como la maneja hoy la Antropología, aplicada a las sociedades occidentales contemporáneas, véase Segalen, Martin, Ritos y rituales contemporáneos. Alianza, Madrid, 2005. 
Como los espectadores de cine, el auditorio del siglo XX está habituado a las butacas. Los oyentes ya no creen en la posibilidad de sobrepasar sus propios límites; ni siquiera imaginan a los compositores como seres distintos, genios, seres inspirados o únicos que participan de una especial sabiduría o locura, y que por ello podrían aportarles una experiencia transfiguradora. El cine-quizá tanto como la ciencia- es el arte que más ha contribuido a esta situación, al eliminar uno de los componentes esenciales de la idea de inspiración: la supuesta espontaneidad. La cámara de video, la colaboración entre centenares de especialistas, el montaje, el recorte de los planos, el artificio de la iluminación, los aparatos de la sala de proyección, junto a la ostentosidad y fetichismo del "mercado capitalista", tan pendiente del "entretenimiento", hacen demasiado explícita al espectador la separación constitutiva entre el público y los creadores, entre el artista y su propia obra. Walter Benjamin Ilamó a esto la "decadencia del aura"60: las obras ya no aparecen como creaciones únicas e irrepetibles inhaladas en el inconsciente, la divinidad o la naturaleza, donde la expresión máxima del artista es cuestión de pura exhalación, sino un continuum de ensayos y errores, de casualidades y necesidades insalvables, de instituciones interpuestas y medios técnicos incapaces de llegar más lejos. La pérdida del aura, es decir, del aire, implica la pérdida de la inspiración.

La idea de inhalar el soplo de una entidad externa parece imposible ante la "desnaturalización" del cine, su "desacralización" y "desencantamiento", utilizando la expresión de Max Weber, que otros Ilamarían "deshumanización", y hace a los artistas demasiado cercanos a los profesionales. El cine despierta la sospecha de que el resto de artistas tampoco han estado nunca inspirados. En el ámbito de la creación musical, el serialismo integral, la aleatoriedad, el indeterminismo, la música concreta, casi al mismo nivel que la música electroacústica, que podríamos remontar al dodecafonismo de Schönberg, donde el compositor (ya alejado del subjetivismo de 1911) parece difuminarse, han amparado esta misma distancia técnica.

Pero aún hay más, pues incluso cuando la obra musical no llega a suponer un corte explícito respecto a la idea de inspiración, la difusión a través de la radio o la televisión, y sobre todo la ingente industria discográfica, con el fenómeno receptivo que la soporta, terminan por dar el último giro a este movimiento distanciador, iniciado con la creación del concepto de "obra" en el siglo XIX: la construcción de un estático e imaginario "Museo Musical"61, en analogía con las pinacotecas, donde se coleccionan objetos irrepetibles, pero que serán repetidos una y otra vez, resulta reveladora en este sentido, tanto en el

60. Benjamin, Walter, La obra de arte en la época de su reproducción mecánica, trad. de Wolfgan Erger. Casimiro, Madrid, 2011.

61. Goehr, Lydia, The Imaginary Museum of Musical Works. Oxford University Press, Oxford, 2007. 
caso de las numerosas interpretaciones de las mismas obras canónicas, como en el caso de la grabación de música antigua, contemporánea o de interés minoritario, que en general se disfruta sólo por este medio, anclado al hogar y sustentado en una idea doméstica de la música.

También la importancia dada a la improvisación virtuosística parece haber perdido aquel halo irracional que tuvo durante el siglo XIX, con Liszt o Paganini. Ya Stravinsky -a pesar del misticismo con que aborda la idea de inspiración- veía en los virtuosos simples ejecutantes, a quienes no se debía permitir "estar inspirados", y así parecen encontrarse en la mente del público, para quien lo importante ha pasado a ser la obra cerrada y definitiva, la interpretación perfecta, sin fallos y sin desviación del guión. Incluso cuando aparece alguien como Glenn Gould (1932-1982) -sobre cuya anormalidad psicológica se ha discutido en exceso, con una mezcla de admiración romántica y distancia científica-, su pureza está tan ligada a la grabación (pues ha sido un gran defensor de la consideración del disco como obra de arte $)^{62}$ que resulta complicado comprender su trayectoria desde la categoría de inspiración. Wilhelm Furtwängler (1886-1954) -en general, reacio a las grabaciones- fue uno de los últimos directores que se mantuvo al margen de esta tendencia: "vivimos en la era de los expertos", lamentaba en 1937, en "la era de la ciencia"63, y recordaba que la relación entre el público y el intérprete debía ser directa, entregada al momento inconsciente de la vivencia del tiempo en común; que la verdadera interpretación estaba al servicio de ese tiempo, y no a una supuesta exactitud previa, que al final convertía al arte, como momento del amor y el sentimiento, en lo contrario de lo que era.

La trayectoria de John Cage (1912-1992) también confirmaría esta situación. Pese a sus propósitos "anti-musicales" (muy similares, sin embargo, a la soteriología de Wagner o Schönberg), su enfoque se encuentra más cerca del serialismo y la experimentación científica con el sonido, heredada del ruido de Russolo y la música concreta de Schaeffer, por una parte, y de las disquisiciones matemáticas y acústicas, esenciales también en Stockhausen, por otra, que de las experiencias "religiosas" o "espirituales" que el autor relata a veces en sus ensayos. Aun habiendo recuperado aquella antigua experiencia de la música como devenir, como el minimalismo de Glass o la música espectral de Grisey, frente al producto que supone una obra de cine o cualquier grabación (en audio o video), ésta tiene algo de imposible por el mundo en el que nace -esto es, el cómodo mundo de las butacas y del sillón doméstico.

Es interesante constatar el parecido entre cierta música contemporánea y las improvisaciones recitadas de algunos rituales religiosos en la India: al dejar que

62. Day, Timothy, Un siglo de música grabada, trad. de Ma J. Mateo. Alianza, Madrid, 2002.

63. Furtwängler, Wilhelm, Conversaciones sobre música, trad. de J. Fontcuberta. Acantilado, Barcelona, 2011, pp. 72 y 77 , respectivamente. 
el sonido fluya por sí mismo, sin imposiciones autorales -se dice-, la especulación estética y las convenciones religiosas parecen dar como resultado un "mundo sonoro" parecido. Pero la diferencia es obvia: nuestra cultura busca esa experiencia desde una instancia privada e individual, donde la escisión entre el público y la música contemporánea es cada vez mayor, referida a un auditorio cultivado y minoritario, durante un periodo de tiempo breve y extraordinario, alejado del momento diario, comunitario, íntimo y cercano propio de la religión. Nos recuerda a la búsqueda de Artaud de un "teatro que induzca al trance": algo que nunca consiguió, ni siquiera después de invocar al inconsciente, a la alquimia y a otras "fuerzas superiores" ${ }^{64}$. Como ha demostrado la mal Ilamada Etnomusicología, el espacio donde se asienta la música no es un adorno, sino la condición de posibilidad de toda escucha, y aquí se persigue una descontextualización que hace absurdos sus propósitos teóricos.

Es por ello, según parece, que la música contemporánea supone un giro radical respecto a la música del pasado. El misticismo del ruido de Cage, su apertura al sonido no-musical, supuestamente liberado y valioso por sí mismo, recuerda a los métodos psicoanalíticos donde cualquier palabra aleatoria merece ser escuchada con reverencia. La escritura automática, cuyos precedentes espiritistas no deberíamos olvidar (como la apelación al sueño o la hipnosis), atraviesa el ingenuo anarquismo y espiritualismo teorizado por Cage $^{65}$, que recuerda a la religión del arte wagneriana o a la actual religión del fútbol, donde la última opinión del más tonto del gremio es recibida con la máxima expectación. Se sobreentiende aquí una inspiración dada al artista, que cree poder hablar de todo sin necesidad de saber de nada, pero sin que sepamos ahora de dónde viene esa inspiración, que simplemente se supone. Entregada al eclecticismo más ingenuo, donde cualquier conjunto de ideas previas pueden ser fundidas, desde la armonía de las esferas o las matemáticas hasta el psicologismo del inconsciente y la intervención divina, la inspiración ha perdido todo su sentido: es un concepto místico por sí mismo, sin ninguna referencia precisa. A Cage podríamos aplicar los supuestos que Paul Valery descubrió tras dicha idea: "La idea de Inspiración -escribió- contiene estas otras: aquello que no cuesta nada es aquello que tiene el máximo valor. Aquello que es lo más valioso no debe costar nada. Y esto otro: Atribuirse la máxima gloria por aquello de lo que uno es menos responsable $e^{\prime 66}$.

Pero aún quedaría por observar la otra cara del problema: ¿qué pasa con toda esa música contemporánea que, todavía hoy, no ha llegado a los escenarios, y que

64. Artaud, Antonin, El teatro y su doble, trad. de E. Alonso y F. Abelenda. Edhasa, Barcelona, 1999, p. 94.

65. Cage, John, Escritos al oído, trad. de Carmen Pardo. Colección de Arquitectura, Colegio Oficial de Aparejadores y Arquitectos Técnicos de Murcia, Murcia, 2007.

66. Citado en Sebold, Russell P., El rapto de la mente. Poética y poesía dieciochescas. Anthropos, Barcelona, 1989. 
sin duda puede competir, en cantidad y calidad, con cualquiera de los siglos precedentes? Si algo puede enseñarnos este breve repaso a la idea de inspiración es la necesidad que tenemos hoy de una estética puesta al día, que haga posible un entorno adecuado a la música actual (a veces obviando las elucubraciones pseudo-filosóficas de los compositores), donde las obras puedan derrochar todo su potencial, sin ingenuos misticismos y sin incluirlas en un contexto extemporáneo.

La inspiración no se reduce al "yo" (cuando esa idea tuvo su máximo apogeo, fue precisamente cuando el auditorio estaba allí para recogerla, en sus templos musicales), pero tampoco al "ser" o al "sonido", que siempre requiere su en-torno. Actuar como si la música viviese aislada en un cosmos flotante, capaz de mostrar su valor por sí mismo a quien consiga ascender a su pompa, supone un mayor grado de ideología que entregarse a las garras del público. Tampoco vale echarle la culpa al Canon o a la Industria Cultural. El problema hoy no es lo que hay, sino lo que no hay: una idea de arte puesta al día, alejada tanto del misticismo dionisíaco como del inefable divino y el esperpento del inconsciente, que siguen operando hoy y que sitúan al arte en una posición ridícula, como la del rey destronado que todavía se cree rey, fomentando obras de arte vacías y actitudes de recepción fetichistas; instituciones que garanticen una difusión inteligente y no se reduzcan a la mera acumulación de virtuosos intérpretes o directores de escena; una educación que reconozca la importancia del aprendizaje artístico y lo fomente, en vez de enseñarnos que los artistas crean de forma pasiva y que los espectadores tienen que aceptar, como imbéciles, cualquier cosa que les echen, aunque no la entiendan.

Precisamente, la última vuelta de tuerca de esta idea confusa y pseudo-religiosa supone que el arte resulta mejor cuando no se entiende ${ }^{67}$ : uno debe esperar que el ruido místico lo despierte. Esta sí es una inversión radical de la mística pitagórica: la idea de inspiración se traslada (democráticamente) al público, aunque sea al coste de quedar reducida al momento fisiológico -ajeno a toda inteligencia- de inspirar. El dogma decadente de la inutilidad del arte, cuya irracionalidad mística lo justifica todo, ha garantizado esta situación consumista, que tiene su reflejo en la forma económica que confunde el objeto útil con el objeto de consumo, en la sordera nihilista que hace del vacío algo superior a lo pleno o en la moda intelectual que no distingue entre ciencia y opinión. Cuando la sociedad es cínicamente relativista y uno debe sentarse en su butaca, echar su voto y cerrar la boca -y esto es así desde el Parlamento hasta la Universidad-, no hay peor remedio que apelar al poder misterioso, salvífico e inefable del arte.

67. Por citar un caso español y reciente, Guadalupe Echevarría -directora de la Escuela Superior de Arte de Burdeos- afirmó que "lo básico del arte contemporáneo es no entender nada", lo que traducía como "vaciarse totalmente para inventarse a sí mismo y así poder entender algo" (El País, 26/03/2013). 


\section{Bibliografía}

ADORNO, T. W., Filosofía de la nueva música. Akal, Madrid, 2003.

ANDRÉS, R., Diccionario de música, mitología, magia y religión. Acantilado, Barcelona, 2012.

ARISTÓTELES, Poética, ed. trilingüe de Valentín García Yebra. Gredos, Madrid, 2009.

-, El hombre de genio y la melancolía (problema XXX), trad. de C. Serna. Acantilado, Barcelona, 2007.

ARTAUD, A., El teatro y su doble, trad. de E. Alonso y F. Abelenda. Endhasa, Barcelona, 1999.

ASENSIO, J. C., El canto gregoriano. Historia, liturgia, formas. Alianza, Madrid, 2001.

BECK, G. L. (ed.), Sacred Sound: experiencing Music in World Religions. Wilfrid Laurier University Press, Waterloo, CA, 2006.

BENJAMIN, W., La obra de arte en la época de su reproducción mecánica, trad. de Wolfgan Erger. Casimiro, Madrid, 2011.

BERNABÉ, A. y CASADESÚS, F. (coords.), Orfeo y la tradición órfica. Akal, Madrid, 2008.

BLUMENBERG, H., La legitimación de la Edad Moderna, trad. de Pedro Madrigal. Pre-textos, Valencia, 2008.

BOECIO, Sobre el fundamento de la música, trad. de J. Luque et al. Gredos, Madrid, 2009.

BRAHMS, J., Cartas (1853-1897), ed. de Hans Gál, trad. de José Aníbal Campos. Nortesur, Barcelona, 2010.

BURCKHARDT, J., La cultura del Renacimiento en Italia, trad. de Teresa BlanCo, Fernando Bouza y Juan Barja. RBA, Barcelona, 2005.

CAGE, J., Escritos al oído, trad. de Carmen Pardo, Colección de Arquitectura. Colegio Oficial de Aparejadores y Arquitectos Técnicos de Murcia, Murcia, 2007.

CICERÓN, De la adivinación, ed. bilingüe de Julio Pimentel Álvarez. Universidad Nacional Autónoma de México, México, 1988.

CLEMENTE DE ALEJANDRÍA, Protréptico, trad. de $M^{\underline{a}}$ C. Isart Hernández. Gredos, Madrid, 1994.

CROFTON, I. y FRASER, D., La música en citas. Robinbook, Barcelona, 2001.

DAHLHAUS, C., La idea de la música absoluta, trad. de Ramón Barce Benito. Idea Books, Barcelona, 1999.

DAHLHAUS, C. y EGGEBRECHT, H. H., ¿Qué es la música?, trad. de Luis Andrés Bredlow. Acantilado, Barcelona, 2012.

DARWIN, C., El origen del hombre, trad. de Julián Aguirre. Edaf, Madrid, 2004.

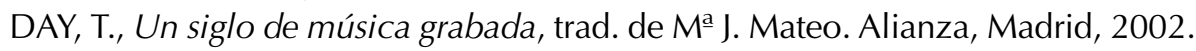


DESCARTES, R., Compendio de Música, trad. de Primitiva Flores y Carmen Gallardo. Tecnos, Madrid, 1992.

DOMíNGUEZ, A. (ed.), Actas del congreso internacional sobre relaciones entre Spinoza y España. Colección Estudios, Universidad de Castilla-La Mancha, 1992.

ELIADE, M., Historia de las creencias y de las ideas religiosas, trad. de J. Valiente Malla. RBA, Barcelona, 2004.

ESCOHOTADO, A., Historia elemental de las drogas. Anagrama, Barcelona, 2011.

ESQUILO, SÓFOCLES y EURÍPIDES, Obras completas, coord. de Emilio Crespo. Cátedra, Madrid, 2008.

FERRER MAS, A. (ed.), Rousseau: Música y Lenguaje. PUV, Valencia, 2010.

FILORAMO, G., Diccionario Akal de las Religiones. Akal, Madrid, 2001.

FOUCAUlT, M., Historia de la Locura. FCE, México, 1999.

FREUD, S., Psicoanálisis del Arte, trad. de Luis López Ballesteros y de Torres. Alianza, Madrid, 2000.

-, El malestar en la cultura, trad. de Luis López Ballesteros y de Torres. Alianza, Madrid, 2000.

FUBINI, E., La estética musical desde la Antigüedad hasta el siglo XX, trad. de Carlos Guillermo Pérez de Aranda. Alianza, Madrid, 2007.

FURTWÄNGLER, W., Conversaciones sobre música, trad. de J. Fontcuberta. Acantilado, Barcelona, 2011.

GOEHR, L., The Imaginary Museum of Musical Works. Oxford University Press, Oxford, 2007.

GRAVES, R., Los mitos griegos, trad. de Esther Gómez Parro. RBA, Barcelona, 2005.

HAMILTON, J. T., Music, madness and the unworking of language. Columbia University Press, New York, 2008.

HARVEY, J., Música e Inspiración, trad. de Carme Castells. Global rhythm, Barcelona, 2008.

HEGEL, G. W. F., Lecciones sobre la filosofía de la historia, trad. de José Gaos. Círculo de Lectores, Barcelona, 1995.

- Enciclopedia de las ciencias filosóficas, trad. de Ramón Valls Plana. Alianza, Madrid, 2008.

HESÍODO, Los trabajos y los días, La Teogonía y El escudo de Heracles, ed. de María J. Leclyse y Enrique Palau. Iberia, Barcelona, 2000.

HOMERO, Ilíada. Odisea, ed. bilingüe de C. García Gual. Espasa, Madrid, 1999. HUARTE DE SAN JUAN, J., Examen de ingenios para las ciencias, ed. de GuiIlermo Serés. Círculo de Lectores, Barcelona, 1996.

JANKÉLÉVITCH, V., La música y lo inefable, trad. de Rosa Rius y Ramón Andrés. Alpha Decay, 2005. 
KANT, I., Crítica del juicio, trad. de Manuel García Morente. Austral, Madrid, 2007.

LINSE, U., Videntes y milagreros. La búsqueda de la salvación en la era de la industrialización, trad. de Rosa Pilar Blanco. Siglo XXI, Madrid, 2002.

NIETZSCHE, F., El nacimiento de la tragedia, trad. de Andrés Sánchez Pascual. Alianza, Madrid, 2010.

—, La voluntad de poder, trad. de Aníbal Froufe. Edaf, Madrid, 2008.

PESET, J. L. y PESET, M., Lombroso y la Escuela Positivista Italiana. CSIC, Madrid, 1975.

PETIT, P., Mozart o la Música Instantánea. Rialp, Madrid, 1993.

PLATÓN, Obras completas. Aguilar, Madrid, 1981.

POE, E. A., Obras completas, trad. de Julio Cortázar, Tomo II. Aguilar, Madrid, 2004.

PRINZHORN, H., Expresiones de la locura: El arte de los enfermos mentales, trad. de María Condor. Cátedra, Madrid, 2012.

QUINTILIANO, A., Sobre la música, trad. de L. Colomer y B. Gil. Gredos, Madrid, 1996.

ROSEN, C., Música y Sentimiento, trad. de Luis Gago. Alianza, Madrid, 2012.

ROS-FÁBREGAS, E., "Historiografía de la música en las catedrales españolas: nacionalismo y positivismo en la investigación musicológica". Codex XXI, Revista de la comunicación musical 1, pp. 68-135.

SAFRANSKI, R., Romanticismo. Una odisea del espíritu alemán, trad. de Raúl Gabás Pallás. Tusquets, Barcelona, 2009.

SAN AGUSTíN, Confesiones. Sarpe, Madrid, 1983.

-, Sobre la música, trad. de J. Luque Moreno y A. López Eisman. Gredos, Madrid, 2008.

SCHÖNBERG, A., Tratado de Armonía. Real Musical, Madrid, 1979.

SCHÖNBERG, A. y KANDINSKY, W., Cartas, cuadros y documentos de un encuentro extraordinario, trad. de Adriana Hochleitner. Alianza, Madrid, 1987.

SCHOPENHAUER, A., Lecciones sobre metafísica de lo bello, trad. de Manuel Pérez Cornejo. Universidad de Valencia, Valencia, 2004.

SCHULTES, R. y HOFMANN, A., Plantas de los dioses: orígenes del uso de los alucinógenos. FCE, 2012.

SCULL, A., La locura: una breve introducción, trad. de E. Jáuregui. Alianza, Madrid, 2013.

SEGALEN, M., Ritos y rituales contemporáneos. Alianza, Madrid, 2005.

SINGER, I., La naturaleza del amor: cortesano y romántico. Siglo XXI, Madrid, 1999.

SPINOZA, Tratado teológico-político, trad. de J. de Vargas y A. Zozaya. Orbis, Barcelona, 1985. 
TOMLINSON, G., Canto metafísico. Un ensayo sobre la ópera, trad. de T. Paul Silles. Idea Books, Barcelona, 2001.

TRÍAS, E., El canto de las sirenas. Galaxia Gutenberg, Barcelona, 2007.

VALLS, M., La música en el abrazo de Eros. Aproximación al estudio de la relación entre música y erotismo. Tusquets, Barcelona, 2002.

VANDENBERG, P., El secreto de los oráculos, trad. de Oliver Strunk. Destino, Barcelona, 1991.

WAGNER, R., La obra de arte del futuro, trad. de J. B. Llinares Chover y F. López Martín. Servei de Publicacions, Universitat de Valencia, Valencia, 2000.

WALTER HILL, J., La música barroca. Música en Europa occidental, 1580-1750, trad. de Andrea Giráldez. Akal, Madrid, 2010. 